\title{
Natural Disaster and Risk-Sharing Behavior: Evidence from Rural Bangladesh*
}

\author{
Asadul Islam ${ }^{1}$, Minhaj Mahmud ${ }^{2}$ and Paul A. Raschky ${ }^{3}$
}

\begin{abstract}
:
This paper investigates how exposure to a natural disaster affects risk-sharing behavior us-ing a unique field experiment in rural Bangladesh. We conducted a risk-sharing experiment that randomly assigned different levels of exogenous commitments to households in disasterexposed and unexposed villages and asked them to form risk-sharing groups. Our results show that disaster-affected individuals are less likely to defect from risk-sharing commit-ments, regardless of the level of ex-ante commitment. Interestingly, this group chose more risky bets and realized higher average returns compared to the non-disaster-affected group. Our results have important implications for the design of financial risk-transfer mechanisms in developing countries.
\end{abstract}

Keywords: Risk preference; risk sharing, intrinsic motivation; asymmetric information; natural disaster; field experiment

JEL Codes: C90; C93; D03; D71; D81; O12; Q54

\footnotetext{
${ }^{1}$ Department of Economics, Monash University; email: asadul.islam@monash.edu.

2 Bangladesh Institute of Development Studies (BIDS); email: minhaj@ bids.org.bd.

${ }^{3}$ Department of Economics, Monash University; email: paul.raschky@ monash.edu.
}

*We would like to thank our dedicated field team. Kashem Khan and Chau Nguyen provided excellent research assistance. We thank Daniel Aldrich and Yasuyuki Sawada as well as participants at the ESA World Meeting in Sydney 2015, the MiniConference on Disasters and Recovery in Tokyo 2016, and seminar participants at Monash University for helpful comments. Funding from Monash University is gratefully acknowledged. 


\section{Introduction}

The vast majority of households in developing countries have no access to formal types of insurance, and therefore more informal types of risk-sharing are often the only way to insure against consumption shocks (Townsend 1994, Holzmann, Packard and Cuesta 2000). There is a substantial amount of existing literature that documents the use of informal risk-sharing networks to counter the adverse income effects associated with sickness and unemployment (Ravallion and Dearden 1988, Fafchamps and Lund 2003), weather shocks (Morduch 1991), and natural disasters (Freeman and Kunreuther 2002, Zylberberg and Gröger 2016).

Considering that informal risk-sharing networks do not rely on formal contracts, an interesting question is whether commitment to informal risk-sharing is stable over time, and in particular, if individual risk-sharing behaviour is affected by the exposure to large negative shocks, such as natural disasters or violent conflict. This question is important because large negative shocks could potentially distort or fully eradicate the only available mechanism that allows households to smooth consumption in poor societies. Eventually, this might have longer lasting adverse effects on the individuals' livelihoods, even after the initial losses of that shock have been absorbed.

There are a number of studies that hint towards the idea that there could be a link between large negative shocks and risk-sharing behaviour. First, large losses affect individual risk preferences, which in turn can impact individual risk-sharing behaviour. A number of empirical studies have confirmed that risk attitudes tend to be systematically affected by large negative events (e.g., Eckel, El-Gamal and Wilson 2009, Malmendier and Nagel 2011, Voors, Nillesen, Verwimp, Bulte, Lensink and Van Soest 2012, Haushofer and Fehr 2014, Page, Savage and Torgler 2014, Cameron and Shah 2015, Hanaoka, Shigeoka and Watanabe 2018). ${ }^{1}$ Further, work by Ghatak (1999), Ahlin (2009), and Attanasio, Barr, Cardenas, Genicot and Meghir (2012) provide evidence of the link between individual risk preferences and the formation of informal risk-sharing groups.

Second, large negative shocks are believed to have a systematic impact on social networks and social capital (Fleming, Chong and Bejarano 2014, Cassar et al. 2017, Toya and Skidmore 2014, Yamamura 2016), which are also important components of risk-sharing networks (e.g., De Weerdt and Dercon 2006, Fafchamps and Gubert 2007, Mazzocco and Saini 2012, Munshi

\footnotetext{
${ }^{1}$ There is no clear consensus in the literature about the effect of natural disasters on risk aversion. One group of studies (Cameron and Shah 2015, Cassar, Healy and von Kessler 2017) find increased risk aversion while another set of studies (Eckel et al. 2009, Page et al. 2014, Hanaoka et al. 2018) finds that people tend to become more risk tolerant after experiencing a natural disaster and that this effect can even persist over multiple years (Hanaoka et al. 2018).
} 
and Rosenzweig 2016). What is, however, absent from the literature is an empirical analysis that directly investigates the relationship between large negative shocks and risk-sharing behaviour.

The purpose of this paper is to fill this gap using data from a field experiment in Bangladesh. More specifically, we exploit the random cut-offs of inundation zones resulting from the 2009 Cyclone Aila in the districts of Khulna and Satkhira to identify the effect of disaster exposure on risk-sharing commitments. Villages that were hit by the cyclone-related flooding are the treatment villages, and the adjacent villages that were unaffected by the disaster serve as control villages.

Our identifying assumption is that the individuals in the flood-affected villages are comparable to the individuals in the unaffected villages. A common concern among studies that use natural disasters as a natural experimental setting (e.g., Page et al. 2014, Cameron and Shah 2015, Hanaoka et al. 2018), however, is that the population in affected and unaffected villages might differ due to some unobservable factors, which simultaneously drive the selection into the treatment group as well as their risk-taking behaviour. For example, more affluent villages could afford better flood protection and also have a different demographic composition, which affects their members' risk-taking commitments.

With respect to this concern, Cyclone Aila and the resulting inundation of Khulna and Satkhira provide a unique setting for a natural experiment. First, man-made protective measures are largely absent, and the few structural measures (i.e., elevated roads) were no match for Aila's storm surge. Second, the study area is located in a large delta on Bangladesh's coast on the gulf of Bengal, and the entire area is flat and lacks significant elevational changes. As such, the topography does not offer any elevated places for settlement that are more protected in the case of flooding. Therefore, the selection into the treatment group is solely driven by the physical magnitude of the cyclone and the resulting storm surge and is, as such, random. To provide further auxiliary support that our identification assumption is valid, we show evidence that the participants in the adjacent villages are similar in a set of observable characteristics.

To measure risk-sharing behaviour, we invited a random subset of households in both the treatment and control villages to participate in a series of lab-style experiments in makeshift laboratories that were set up in each village. The design of this lab-in-field type of experiment closely follows the design of Barr and Genicot (2008). In the first step participants had to choose 
from different lotteries in a standard risk taking game. ${ }^{2}$ In the second step, they were asked to form a risk-sharing group that pools and shares the gains from the group members' gambles. Then, assigned into one of the three different information treatments. Those treatments varied with respect to the level of exogenous commitments that allowed individuals to defect and whether such a defection was public or private information.

The main finding is that participants in disaster-affected areas are more risk loving and are less likely to defect in risk sharing commitment regardless on the level of exogenous commitment and information.

Our study's main contribution is building an empirical link between the literature on the impact of large negative shocks on risk preferences and research on the nexus between individual risk preferences and risk-sharing behavior. A growing body of empirical literature provides evidence that individual risk preferences are not stable over time (e.g., Lowenstein and Angner 2003, Malmendier and Nagel 2011) and, in particular, traumatic events such as natural disasters can affect individuals' risk preferences (e.g., Eckel et al. 2009, Page et al. 2014, Cameron and Shah 2015, Hanaoka et al. 2018).

Large negative shocks can affect risk-sharing behaviour through their effect on individual risk preferences. While Ahlin (2009) finds evidence of assertive matching based on risk preferences in risk-sharing groups in general, Attanasio et al. (2012) reveal that this is only the case for groups with strong social networks. To our knowledge, our paper is the first one that combines the idea to use disasters as a natural experiment from the former strand of literature and combine it with the methods for investigating risk-sharing behaviour in an incentivized manner from the latter strand of literature.

Our findings are of particular importance for the literature that deals with decision making under uncertainty with respect to low-probability-high-loss (LPHL) events (e.g., Kunreuther 1996, Kunreuther, Novemsky and Kahneman 2001, Kunreuther and Pauly 2002, Browne, Knoller and Richter 2015). In line with existing studies (e.g., Page et al. 2014, Hanaoka et al. 2018), we confirm that the recent exposure to a natural disaster makes people less risk averse. This could be problematic if this adversely affects the individuals' willingness to prepare for such LPHL events that are already prone to under-insurance. However, the result of our second experiment suggests, that despite becoming more risk tolerant, individuals are also more likely to commit to risk-sharing

\footnotetext{
${ }^{2}$ The design in the first stage is also used by other related studies in this literature such as Carvalhoa, Prinab and Sydnor (2016) or Cameron and Shah (2015).
} 
institutions. This could be an indication that the affected individuals do not necessarily shirk risk-sharing responsibility despite becoming less risk-averse. As such, our results also provide new insights for the economic research on the demand for disaster insurance. In particular, we offer an additional explanation why individuals tend to underinsure against LPHL events such as natural disasters (Botzen and van den Bergh 2012, Gallagher 2014, Kousky 2010, Kunreuther 1996, Kunreuther, Meyer and Michel-Kerjan 2009, Landry, Ahmadiani and Colson. 2016, Petrolia, Landry and Coble 2013, Raschky, Schwarze, Schwindt and Zahn 2013).

This can inform economists and policy-makers trying to explain why the level of disaster insurance is below an optimal social level (Kunreuther 1996, Kriesel and Landry 2004, Kunreuther et al. 2009, Raschky and Weck-Hannemann 2007, Kousky, Michel-Kerjan and Raschky 2018) and who want to design more efficient financial risk-transfer mechanisms against natural disasters.

We also relate to the literature on the role of intrinsic motivation in forming risk-sharing groups. Informal risk sharing, in theory, can be described as repeated games among self-interested individuals and among parties who are intrinsically motivated by feelings of altruism, and risksharing is hindered by asymmetric information about others' income and shock when people engage in risk sharing groups (Ligon, Thomas and Worrall 2002). Barr and Genicot (2008) suggest that both extrinsic incentives, such as social sanctions, and intrinsic motivations, such as altruism, reciprocity, and aversion to inequality can induce commitments that lead to efficient risk sharing. These experimental findings suggest that extrinsic incentives crowd out intrinsic motivation and highlight the importance of identifying the distinction between extrinsic and intrinsic motivation in risk-sharing behavior (Cardenas, Stranlund and Willis 2000, Bohnet, Frey and Huck 2001). In this context and allowing for the possibility to defect in our experimental design, our findings may also be relevant for the experimental economics literature on risk aversion in groups (Sutter 2007) as well as punishment and social sanctions in public good games (Sutter, Haigner and Kocher 2010).

The remainder of the paper is organized as follows: In Section 2, we provide a brief description of the disaster in question and the physical impact it had on the community. In Section 3, we discuss the experimental design that we adopt in this paper, which closely follows Barr and Genicot's (2013) design. Section 4 presents the field experiment and the data. Section 5 discusses the results and Section 6 concludes. 


\section{Cyclone AILA}

The Cyclone AILA struck the southwestern coastal region of Bangladesh (and the eastern coast of the neighboring West Bengal province of India) on the 25th of May 2009. The Satkhira and Khulna districts were the worst hit, with nine other districts in Bangladesh also badly affected. Hitting during high tide, the cyclone brought with it tidal surges of up to 6.5 meters (Nations 2010). In the Khulna and Satkhira districts, several rivers broke through embankments, causing widespread inland flooding. This surge of water damaged and washed away embankments, removing the only protection available to many people along the coast. According to Nations (2010), the immediate impact of AILA resulted in 190 deaths and approximately 7,100 injuries, with over 3.9 million people being affected, along with the death of 100,000 livestock and the destruction of 350,000 acres of cropland. It also caused considerable infrastructure losses. Thousands of kilometers of road were damaged or totally destroyed, and hundreds of kilometers of flood protection embankments were washed away. More than a million people were displaced and several hundred were killed in Satkhira and Khulna, which were the worst affected districts.

The main damage was caused by flood water breaching the already weakened embankments throughout the affected districts. Activities associated with shrimp farming, such as the frequent practice of opening the embankments to move saline water into shrimp ponds, made the halfcentury-old earthen embankments weak, causing them to break during the tidal surge inflicted by the cyclone. Silting up of the river beds, along with rapid coastal subsidence, have also contributed to higher tidal surges and increased strain on the embankments. The area remained waterlogged for a prolonged period, salinizing the soil and inland water. As a result, agriculture in the region was badly affected, and people in the region suffered from an acute scarcity of drinking water.

Eight months later, the repair of the embankments was far from complete. Due to a lack of land and funds, there were far fewer reconstruction support programs, and thousands of families remained more vulnerable to future flooding. The AILA survivors were again affected in February and March of 2010 from flooding resulting from breached river embankments due to high tides. Communities that were starting to recover from AILA again had their homes, crops, and infrastructure destroyed. The government efforts to repair the damage were not timely, which caused the embankments to collapse due to water pressure during new moon tides. Embankments that were damaged by AILA were either not rebuilt at all or not rebuilt properly. In many areas, 
the damage to the network of embankments in the 2010 flood resulted in a prolonged continuation of negative effects on communities. Breeches in the embankments, which become severe during daily high tides and particularly during full moon periods, prevented high levels of selfrecovery. The damage to the coastal embankment network was severe and directly contributed to the continuation of the post-cyclone 2010 flood (widespread flooding and tidal inundation). ${ }^{3}$

The government of Bangladesh, in coordination with non-government organizations (NGOs), international organizations, and bilateral donors, rapidly responded to the flood emergency and assisted the affected population. The government provided the bulk of the relief assistance, including food, cash, drinking water, emergency medicine, and other non-food materials to AILA-affected communities. Although there was an absence of a formal appeal, the international community provided assistance to many national and international organizations and government agencies working in the most affected areas.

Although flooding is a natural and common phenomenon in Bangladesh, AILA had a large impact on local households. The AILA-hit area, located in southwest Bangladesh, is characterized by low-lying lands protected by embankments and surrounded by water. It is home to households who primarily make a living from agriculture, forestry, fishing, and shrimp farming. Unlike in other coastal areas, such flooding is very uncommon in this coastal area of Bangladesh, as it is protected largely by Sundarban, the largest single block of tidal halophytic mangrove forest in the world. Thus, such largely unanticipated shocks could have significant impacts on the economic and social lives of the people in the area.

\section{Experimental Design}

The purpose of our experiment was to investigate how disaster exposure affects risk-taking and risk-sharing. Using information from a previous survey conducted in 2010, we outlined the treatment-control set up, whereby we identified villages affected by the 2009 AILA disaster to serve as treatment villages and the nearby unaffected villages to serve as controls.

Figure 1 shows the locations of the treatment and control villages with respect to the flooded areas. Figure 2 shows the locations of the treatment and control villages overlapped with a digital

\footnotetext{
${ }^{3}$ We conduct the survey immediately after flood in 2010 event, and conducted experiment two and half years after this flood during December 2012 - January 2013. Although the flood in 2010 is after 2009 AILA cyclone, it is hard for the affected people to assess the impacts of the two events separately since the same communities were affected by both events in 2009 and 2010.
} 
Figure 1: Sample Villages and Inundated Area

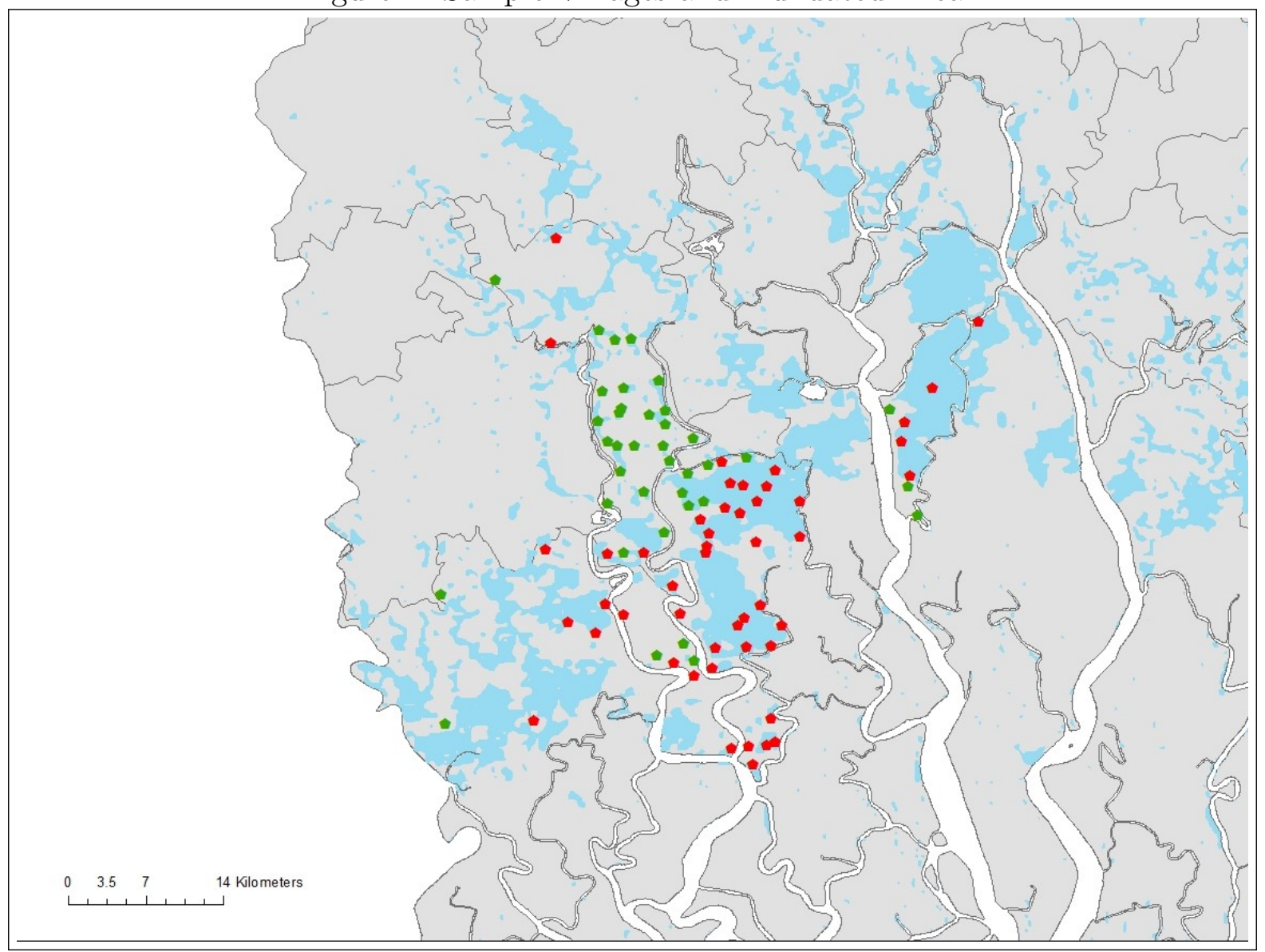

Note: This figure displays the location of the treatment (red) and control (green) villages and the inundated areas (blue). White and thin grey lines indicate waterways. (The large wide area to the west is land area that belongs to India)

elevation model ${ }^{4}$ of the area. The mean elevation of the treatment villages is 9.04 meters, whereas the mean elevation of the control villages is 9.25 meters.

Households were randomly selected from both types of villages: disaster-affected (treatment) and non-affected (control) villages. We have comprehensive information about these households at baseline and at a follow-up conducted in 2012-13.

In 2010, we surveyed the disaster-affected villages for a different purpose: to understand the magnitude of the loss due to a disaster and the coping mechanisms used by disaster-affected people. At the same time, we had another survey ongoing in the nearby non-disaster villages (and some disaster-affected villages) as part of the baseline survey of a randomized field experiment on education. Hence, disaster and non-disaster areas in this survey were not planned and were

\footnotetext{
${ }^{4}$ We used the ASTER L1B data product was retrieved from the online Data Pool, courtesy of the NASA Land Processes Distributed Active Archive Center (NASA LP DAAC, 2015), USGS/Earth Resources Observation and Science (EROS) Center, Sioux Falls, South Dakota (https://lpdaac.usgs.gov/data_access/data_pool)
} 
Figure 2: Sample Villages and Inundated Area

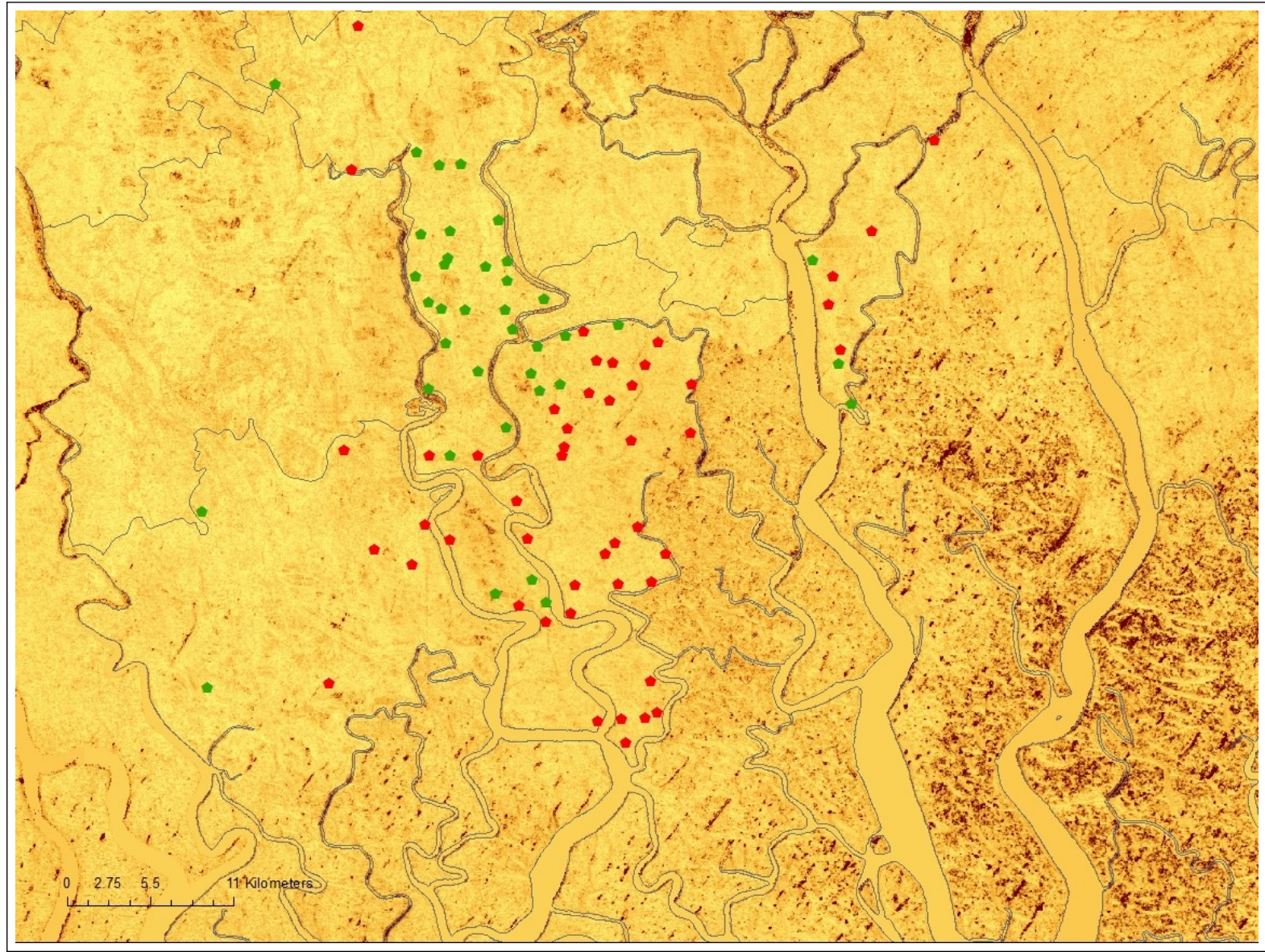

Note: This figure displays the location of the treatment (red) and control (green) villages and the elevation. Lighter orange indicates lower lying areas, darker orange/brown indicates elevated areas. 
initially chosen for different purposes. As a result, we do not have a balance in the characteristics among households between disaster and non-disaster villages when we consider the full sample from these villages. Thus, the subjects in the experiment in the disaster and non-disaster areas differ across numerous observable characteristics. To allay concerns about confounding variables, we used covariate matching and selected a subsample from both treatment and control villages composed of participants who were similar in terms of age, education, gender, and income. We report results using this matched sample in the Appendix. In addition, because the level of disaster exposure also varies across communities/villages, we created, within the affected villages (treatment villages), a disaster affectedness index using information related to various levels of exposure to a disaster. ${ }^{5}$ This index was then used as a level of exposure to a disaster that we could utilize to check the robustness of our principal findings. In the latter case, we considered only villages affected by flooding that were affected disproportionately because of the natural disaster, and hence the level of exposure to a disaster is exogenous.

For the experiment, a total of 45 villages were selected randomly from our survey villages. Of these, 24 are from disaster-affected areas and 21 are from non-disaster areas. The number of individuals in different versions of the risk-sharing game is shown in appendix Table 1. We invited the adult members of the same households that responded to our survey in 2010 to participate in our risk-taking game or gamble choice game in two different rounds.

One potential concern is that migration due to a disaster could cause the sample to be biased. If, for example, risk-averse individuals leave their villages in anticipation of or in response to a disaster, our results will be biased due to sample selection. In rural Bangladesh, most families live on their ancestral land, and moving away from one's village is uncommon. Most of the households in these areas live below the poverty line and live on a plain (there are no hill tracts). A study by Gray and Mueller (2012) found that the movement out of villages in response to disasters such as floods is very limited in Bangladesh. Instead, they found that crop damage unrelated to a disasters is the major cause of migration. Moreover, we conducted the experiment almost two and half years after the disaster was over; hence, many people who had migrated from the region had returned to the area. Hence, migration is not a major issue in our case.

\footnotetext{
${ }^{5}$ The exposure index of a village is a weighted index (with value from 0 to 1 ) created based on how much that village is affected in 12 different aspects. The 4 most important aspects (agro-crops, domestic animals, road, house) account for $80 \%$ of the total weight. The remaining $20 \%$ weight is made up by the 8 less important aspects (dam, educational institutions, government offices, electricity, water, fish gar, tree plantation, water height). The exposure in each aspect is indicated in either one of three levels: low, average, and high. We give these numerical values of 1,2 , and 3 respectively.
} 
The people who attended the experiments are the adults who make financial decisions in their families. In the first round, each participant chooses their preferred gamble from a series of six gambles presented to them. The gambles differ in terms of riskiness and expected payoff, with higher risks associated with larger expected payoffs. Once the choice is made, depending on the outcome of a coin toss for the chosen gamble, the payoff is recorded and given to the respondents after all experiments are completed. The choice of gamble by the participants allows us to understand their risk preferences. We followed this simple experiment to elicit risk preferences because simple methods have been found to be useful in trying to capture treatment effects and differences in individuals' risk preferences (Charness, Gneezy and Imas 2013).

In round 2, we conducted a risk game similar to the one described above, except the participants were invited to form risk-sharing groups (described to them as "income sharing" groups), in which they played a similar gamble choice game but pooled their individual earnings from the gamble (if any) and agreed to share the pooled income equally with their group members. However, individuals were not forced to form groups, meaning that they could play alone in this round. Once a group was formed, the group members were required to abide by the sharing rules described to them beforehand. This second round experiment allowed us to measure the risksharing preferences of individuals, whereby we were able to understand whether people tend to form risk-sharing groups, and if so, to determine the typical size of a risk-sharing group. Finally, we investigated the relationship between risk attitude and the formation of risk-sharing groups (in terms of group size).

We formulated several hypotheses regarding the formation of risk-sharing groups within our study population. Cohesiveness and connectedness are essential to effective risk management in any community (WDR 2014). Following Solnit (2009), who suggests that disasters can increase cooperation among people, it is reasonable to assume that disaster exposure promotes cohesiveness and social ties through the channeling of different forms of social capital. For example, based on experimental findings from a dictator game and a public good game, Whitt and Wilson (2007) predicted higher degrees of cooperation among individuals who were evacuated from New Orleans to Houston shelters in the aftermath of Hurricane Katrina. Cassar et al. (2017) found increased trust among 2004 Tsunami-affected people in Thailand, which was largely driven by positive experiences and help received in the aftermath. Fleming et al. (2014) suggested that a postdisaster environment could alter the social capital of a community by affecting norms, attitudes, 
and behaviors. For example, experiences of generosity or help from unrelated others, during or after the disaster, may make people more trusting, and feelings of reciprocity or expected cooperation may make people more trustworthy and cooperative. ${ }^{6}$

On the other hand, negative experiences or feelings of abandonment in the face of disaster may also make people distrustful towards others. By comparing the outcomes of a trust game in earthquake-affected and non-affected villages one year after the 2010 Chilean earthquake, Fleming et al. (2014) found lower levels of reciprocity in affected areas. Following the above, we assume that disaster-affected villagers would be more willing to form risk-sharing groups. This is because expost disaster experiences may trigger intrinsic motivations, such as concern for fairness, inequality aversion, and cooperative instincts, which can play powerful roles in inducing commitments for risk sharing, resulting in more risk sharing among groups affected by the disaster. Again, due to intrinsic motivation, defection in risk-sharing commitment will be less pronounced regardless of the level of information and exogenous commitment to risk sharing. However, ex-post disaster environments can also affect the level of trust and reciprocity of individuals exposed to negative experiences, thereby reducing the probability of risk sharing. In such cases, incomplete information may cause distrust, making risk sharing less likely. More risk-sharing arrangements can also potentially lead people to take more risks to obtain higher rewards and also cause them to join a trustworthy group to pool those risks. Given our hypotheses, we would like to distinguish between the roles of external incentive (such as a social sanction) and intrinsic motivation in risk-sharing behavior. Following the experimental design of Barr and Genicot (2008), we therefore introduce a control and three additional information treatments to be randomly assigned to our original treatment (disaster-affected) and control (non-affected) households. First, we introduced a control group without any risk-sharing option. This no-risk-sharing group played the same gamble choice game as in the first round. Three risk-sharing treatment groups were then created related to different risk-sharing commitments, such as full exogenous commitment, limited commitment with the possibility of secretly leaving the group (private defection) after learning one's personal payoff from the gamble, and limited commitment with the possibility of leaving the group and letting others know (public defection) after learning one's personal payoff from the gamble. We explain the three information treatments with regard to the risk-sharing rules that we adapted

\footnotetext{
${ }^{6}$ Psychological evidence suggests that suffering in the aftermath of a crisis can lead to an increased sense of personal strength, changed priorities, and more meaningful interpersonal relationships, which in turn provides support for the hypothesis that trust may increase after a natural disaster
} 
from Barr and Genicot (2008) as follows:

1) Full information and full exogenous commitment: Individuals are allowed to form risk (income)-sharing groups before choosing a gamble for a lottery payout. Each member of the group will share the realized group earnings from the gamble equally, irrespective of their individual gamble payoffs. After learning the outcome of their personal gamble payoff, the members will not be allowed to withdraw from the group. Thus, the risk-sharing decision is binding.

2) Limited exogenous commitment (with private defection): Individuals are allowed to form income-sharing groups, but the commitment to income sharing is limited in that they are allowed to withdraw, in private, from their group after learning their individual payoff from the chosen gamble. This means that other group members will not know if someone has defected (private defection). It is assumed that the possibility of social sanctions may not encourage individuals to stay in their groups because the identities of defecting individuals will not be disclosed. Knowing this ahead of their decision-making, individuals are assumed to form groups within trustworthy networks of individuals who are not expected to defect. It is likely that fear of defection results in lower rates of group formation or risk sharing. If instead we observe more risk pooling and less defection under this treatment, then it would imply that intrinsic motivation is stronger in inducing risk-sharing commitments.

3) Limited exogenous commitment (with public defection): Individuals are allowed to form income-sharing groups and subsequently withdraw from them after discovering their own income from the gamble if such a defection is made in public. This means that if an individual prefers to quit her group and take her own gambling income, other group members will be informed of her defection. However, the defector's earnings from her gamble will not be known to others. This treatment allows the possibility of social sanctions in response to defections, and, knowing this ahead of group formation, individuals might choose to join groups where the chance of implementing such sanctions is less likely (such as groups of friends or close family members).

Therefore, we elicit the risk-sharing and risk-taking behavior of our households in our treatment and control villages under each of these risk-sharing rules. For reasons of comparability of our findings, we will primarily focus on the following measures of risk sharing: 1) decision to join the risk-sharing group, 2) size of the risk-sharing group, and 3) riskiness of the choices made under the risk-sharing arrangement

It is hypothesized that if members joining a group choose riskier gambles, this would suggest 
that they are pooling more risk to maximize expected returns. Following our hypotheses above, we will compare this risk-sharing measure across treatments to see how limited commitment and asymmetric information about defection induces risk pooling among disaster-affected households in comparison to non-affected households.

\section{Subjects and the Field Experiment}

Our sample consists of villagers exposed to the AILA disaster (in 2009) in the Satkhira and Khulna districts of Bangladesh. Using the information from a previous baseline survey, we identified villages affected by this disaster to serve as the treatment villages in our experiment, and we identified nearby non-affected villages as control villages. Our final sample included 24 treatment and 21 control villages. About 25-35 households from each village that were interviewed for the survey were invited to participate in the experiment. The experiment was preceded by a short survey to verify the household identities and basic demographic and socio-economic characteristics of the participants. All individuals took part in two rounds of the risk game discussed above. The first round consisted of a simple lottery choice game. In the second round, a subsamples (defined as the control group for risk sharing) only participated in the same risk game, while three other sub-samples of villagers within both the treatment and control villages were assigned to three different risk-sharing rules, characterized by different levels of exogenous commitment and information.

The households participated in two rounds of experiments in the morning and in the afternoon/evening of the same day. Trained enumerators conducted experiments face to face with the respondents in a one-to-one setting. In the risk game, the subjects were presented with six gambles, which were ordered from least risky to most risky, keeping the probability of winning and losing, in each gamble, equally likely. The first gamble offered a guaranteed payout; an individual who chose the first gamble, regardless of the lottery results, received 100 Taka. After recording the subject's choice of gamble, the enumerator then conducted the coin toss and recorded the result; at the end of the round, each person received her earnings from the gamble. If the coin turned up heads, she received the high payoff, and if the coin turned up tails, she received the lower guaranteed payoff of 100 Taka. The gambles were described using pictures of paper bill notes next to the payoff amount and pictures of coin sides attached to each outcome (see figure) 
to facilitate the participants' comprehension of the exercise. Before the actual choice, the context was presented, and the subjects were provided with examples and training on the coin toss experiment to facilitate their understanding of the probabilities in the game.

After the first round, the participants' income from the lottery was recorded, they were told about the second round of experiments, and they were informed that payouts from both rounds would be distributed in private once everything was over. In the risk-sharing treatment groups, the participants were privately informed that in the second round they would be playing the same game but would have the opportunity to form their own groups to pool their members' incomes. Each individual from the first round was told that he or she was free to form a group with anyone (including strangers). Once individuals submitted the group members' names, they were asked several questions about the group members' identities and their relationships with the individuals being questioned. After all the information was carefully recorded, the subjects were privately interviewed and made decisions in the risk games.

The rules and financial implications of (income-sharing) group formation in each case were explained using examples until everything was clear to the subjects. The subjects were told that groups could consist of as many individuals as they could prefer and that the group members would be friends, family, neighbors, or any other villagers, even strangers. The researchers explained to them that by forming a group, all group members were, by default, agreeing to share the total group income from the gamble choice lottery equally, regardless of what an individual member actually earned from their own choices in the gamble. They were also informed that if the total earnings were zero, no one in the group would receive any money. Similarly, if all but one participant received zero earnings in the individual lotteries, then the single earner's income would be divided equally among all the group members. The individuals were told that this rule of group formation ensured that losers would be compensated with the gainers' income, which is the essence of income sharing. It was also explained that individuals would not be allowed to change their minds after declaring a group, that is, they could not refuse to share earnings with others in the group. Regardless of their individual outcomes, group members' earnings would be pooled and shared equally.

In cases of limited commitment treatments (private as well as public defection), subjects were given the opportunity to leave the group, taking their personal income. Such defection decisions were recorded immediately, and the defecting individual's earnings were not added to the 
respective group's total. However, all earnings were paid at the end. The enumerators recorded the defection decisions and subsequent earnings first. After calculating everyone's earnings, they informed each subject of their private earnings. They then recorded whether the subject would like to leave the group with her personal earnings or stay in the group to pool everyone's income. The summary statistics show that the disaster and non-disaster are not balanced across a number of demographic characteristics. We address this in two ways. First, we include the demographic variables as additional control variables in our specifications. Second, in Appendix B, we present our main results using a balanced sample. The results stay qualitatively the same.

Table 1 reports the respondent characteristics.

\section{Table 1 about here}

The protocol and instructions used in the experiment are presented in the Appendix A.

\section{$5 \quad$ Results}

In this section, we discuss the results of the risk-taking and risk-sharing experiments. We found that $35.2 \%$ of the participants (standard deviation 0.47 ) chose risky bets (gamble 5 or gamble 6 ). In Table 2, we present the distribution of the gambles along with the subjects' (disaster-affected and non-affected households) choices and differences in choices between the two groups, focusing on the first round. We found significant differences in the context of risk taking between these two groups: Among the disaster-affected villagers, 40\% chose risky bets, and among the nondisaster-affected villages, $29 \%$ chose risky bets. This significant difference in risk-taking behavior suggests that individuals directly exposed to a disaster may become more risk tolerant than those not directly affected by the disaster. This result is consistent with the findings of Eckel et al. (2009), which also provide experimental evidence of increased risk seeking behavior immediately after a disaster (hurricane) in the USA. In addition, Li, Li, Wang, Rao and Liu (2011) provide survey evidence from China that people become risk seeking in order to secure increased gains.

\section{Table 2 about here}

We examined the probability of risk taking. The results from the probability analysis reported in Table 3 suggest that individuals from disaster-affected villages were more likely to take risks. 
The results were robust to the inclusion of other individual characteristics, such as age, income, and education, as well as village-fixed effects. Interestingly, we also found that, controlling for disaster exposure, women and poorer households exhibited more risk aversion, whereas people with more education exhibited less risk aversion (or higher risk appetite). However, we also observed that within the disaster-affected villages, the households that were more inundated with water were less likely to take risks.

\section{Table 3 about here}

\subsection{Risk Sharing}

We focused primarily on the three measures of risk sharing: 1) group formation (whether the individuals decided to join the risk-sharing group or decided to play alone in the second round of the experiment), 2) group size (conditioned on group formation, the size of the group an individual chose to form), and 3) the riskiness of the chosen gamble (conditional on group formation for risk sharing, for example, if members join a group choosing risker gambles, this would suggest that they are pooling more risk to maximize the expected return). Then, we compared these behaviors between disaster and non-disaster samples and also under different information treatments. That is, we compared how limited commitments and asymmetric information about defection affected risk-sharing behavior in our study population. For example, as suggested by Barr and Genicot (2008), if under limited information conditions and the possibility of private defection we observed more risk sharing and less defection, this would suggest that intrinsic motivation primarily induces risk-sharing commitments. Following Solnit (2009), we would then expect this to happen among the disaster-affected group. Indeed, we found higher risk-sharing attitudes, in terms of likelihood of group formation and the size of the groups, among the non-disaster-affected group. However, defection was less likely among disaster-affected groups, regardless of information treatment. Again, among non-disaster groups, larger groups formed under full information than under limited information conditions, whereas among the disaster-affected sample, group sizes were larger under limited information conditions. In the disaster-affected population, we also observed a higher tendency to choose risky gambles under private defection treatment by the disaster group. These observations suggest that lower levels of defection among more risk-pooling groups imply that intrinsic motivation primarily induces risk-sharing commitment. 


\subsection{Group Formation}

We observed that about $94 \%$ (out of 1,234) subjects formed groups in order to share income from the risk taking in round 2. The proportion of individuals forming risk-sharing groups was $6 \%$ higher (97\% out of 578 , versus $91 \%$ out of 656 ) among the non-disaster-affected group. Interestingly, the proportion of individuals willing to form risk-sharing groups was significantly higher among the non-disaster group under all three treatments; the differences between these two groups with regards to group formation were $5 \%, 7 \%$, and $6 \%$ under defection, private defection, and public defection treatments, respectively. The extremely high percentage of individuals (over 90 percent) who chose to form risk-sharing groups and the higher percentage of individuals who chose risky bets in round 2 compared to round 1 suggest that the participants understand the benefit of risk sharing.

As reported in Table 4, the likelihood of joining a group was higher in the non-disaster sample. However, we did not find any differences across information treatments in terms of the likelihood of group formation. Interestingly, winning in a round 1 gamble negatively predicted the likelihood of joining a group. In addition, winners in round 1 formed significantly smaller groups during the risk-sharing game in round two.

\section{Table 4 about here}

The average group sizes were 4.44 and 4.88 among the disaster-affected and non disasteraffected groups, respectively. The group sizes were significantly higher under full information and private defection conditions for the non-disaster-affected sample than for the disaster-affected sample. Group sizes were higher among non-disaster-affected individuals than among disasteraffected individuals under both full information and private defection treatments. Within the non-disaster group, group sizes were higher under full information treatment (5.03) than under asymmetric information treatment (4.88). Conversely, within the disaster group, group sizes were higher under the asymmetric information treatment (4.61) compared to the full information treatment (4.00). This essentially distinguishes the motivations for risk sharing between the treatment and control group. Conditional on the likelihood of joining a group, we regressed group size on main treatment (disaster affectedness) and information treatments, as well as on other relevant variables (see Table 5). The standard errors were clustered at the village level to account for the fact that group formation might represent a social process within the villages. 
Although we did not find any significant effects of information treatments on group size, we found that group size was significantly smaller among the disaster-affected participants.

\section{Table 5 about here}

\subsection{Defection}

We now look at defection under two treatments: private and public. As reported in Table 6, generally (pooled sample), less defection is observed under the treatment of public defection (21\%) than under private defection $(26 \%)$, suggesting that, generally, people opt out more when exogenous extrinsic commitment is limited. In other words, group members may be more hesitant to leave the group when social sanctions are likely. Subjects who are more likely to defect are less likely to be selected under public defection treatment due to the fear of social sanctions. We observed significantly more defection among non-disaster groups under public defection and private defection; however, we observed less defection among disaster affected people. The difference between these groups is higher in the case of private defection (0.34 person in non-disaster area versus 0.08 person in disaster area) than public defection ( 0.24 person in non-disaster area versus 0.03 person in disaster area), suggesting that the non-disaster-affected group defected less under the public defection treatment than under the private defection treatment.

\section{Table 6 about here}

However, as reported in Table 6, overall defection was much lower among disaster-affected people; only $5 \%$ left the group, as opposed to $28 \%$ of the non-disaster-affected group. It is quite interesting to note that, although the non-disaster-affected sample formed risk-sharing groups at a higher percentage under each treatment (p-value 0.024, 0.027, and 0.029 under no defection, private defection, and public defection, respectively), they also tended to defect at higher percentages under each information treatment (26\% and $21 \%$ higher defection rates for nondisaster-affected villagers compared to disaster-affected villages under both treatments, private defection and public defection).

Finally, we analyzed the probability of defection (see Table 7) and found that disaster-affected groups were less likely to defect, controlling for winning the gamble, risk taking, and other variables such as gender, education, and age. Interestingly, winning predicted defection; winners 
were more likely to defect. However, we did not find evidence that risk preference (risk loving) has any significant effect on defection. The fact that disaster-affected people form smaller groups and are less likely to defect from risk sharing may suggest that they select themselves into groups on the basis of general trust and solidarity. This is also confirmed by the observation that disaster-affected people less likely to choose from near neighbors (significantly over $10 \%$ percent less under each treatment) but more from distant neighbors (11\% more under private defection treatment) in the group (see Table 6). This suggests that individuals are much more driven by intrinsic motivation and pro-social behavior in the ex-post disaster environment. This is also consistent with the hypothesis that individuals are less likely to be selected into a group if they are expected to defect. Although the disaster-affected group members were less likely to form risk-sharing groups, once they formed them, they were less likely to defect, suggesting that risk sharing (group formation) follows from feelings of cohesiveness, trust, and inequality aversion.

\section{Table 7 about here}

As a robustness check to our main findings, we conducted a similar analysis focusing on only the disaster villages, defining the level of exposure to a disaster. The results reported above are similar (see Appendix) when focusing on disaster-affected villages, implying that our conclusions on risk-sharing and risk-taking behaviors are robust to the identification of disaster exposure. The overall results suggest that the more an individual is exposed to a disaster, the more likely she is to take risks, and the less likely he or she is to share risks. The results are also similar when we examine the different risk-sharing commitments.

In a second robustness check we address the issue that the full sample is not balanced across a number of of demographic characteristics. We therefore, create a balanced subsample from the full sample data and re run the models from our main results in Tables 5 and 7 . The results stay qualitatively and quantitatively the same and are presented in Appendix B.

\section{Conclusion}

We investigated how disaster exposure affects risk-sharing behavior using a unique field experiment in rural Bangladesh. Generally, we observed substantial risk-sharing and risk-taking behaviors among both disaster-affected and unaffected individuals in our sample. We observed less defection under public information than under private information of defection. Our results suggest 
that disaster-affected individuals are less likely to defect from risk-sharing commitments, regardless of the level of ex-ante exogenous commitment. More interestingly, this group significantly choose more risky bets and also realized a higher average return than the non-disaster-affected group. These results suggest that enhanced risk sharing ex-post disaster exposure is driven by intrinsic motivation and pro-social preferences, such as trust, reciprocity, and altruism rather than external incentives, such as social sanction. This result is consistent with the assertion made by Solnit (2009), that disasters are often catalysts for increasing social capital. Solnit (2009) reports various examples of mutual support, generosity, and greater degrees of participation in disaster-affected communities, suggesting that such effects may persist in the aftermath of a disaster. Although the probability of joining a risk-sharing group might be affected by the degree of disaster affectedness (weak evidence in terms of statistical significance), which also affected the sizes of the risk-sharing groups, we found strong evidence that disaster-affected people are less likely to defect once they enter into a risk-sharing commitment. Our results also suggest that intrinsic motivation and pro-social preferences can amend market failure in risk management. That disaster makes people more risk seeking can be explained by the fact that people build resilience by living through disasters and adapt to survive. 


\section{References}

Ahlin, Christian, "Matching for Credit: Risk and Diversification in Thai Micro-Credit Borrowing Groups," Michigan State University mimeo, 2009.

Attanasio, Orazio, Abigail Barr, Juan Camilo Cardenas, Garance Genicot, and Costas Meghir, "Risk Pooling, Risk Preferences, and Social Networks.," American Economic Journal: Applied Economics, 2012, 4 (2), 134-67.

Barr, Abigail and Garance Genicot, "Risk Sharing Commitment and Information: An Experimental Analysis," Journal of the European Economic Association, 2008, pp. 6 (6): 11511185.

Bohnet, Iris, Bruno S. Frey, and Steffen Huck, "More Order With Less Law: On Contract Enforcement, Trust and Crowding," American Political Science Review, 2001, 89, 335-339.

Botzen, Wouter J. and Jeroen van den Bergh, "Risk Attitudes to Low-Probability Climate Change Risks: WTP for Flood Insurance," Journal of Economic Behavior and Organization, 2012, 82 (1), 151-166.

Browne, Mark J., Christian Knoller, and Andreas Richter, "Behavioral Bias and the Demand for Bicycle and Flood Insurance," Journal of Risk and Uncertainty, 2015, 50 (2), $141-160$.

Cameron, Lisa and Manisha Shah, "Risk-Taking Behavior in the Wake of Natural Disasters," Journal of Human Resources, 2015, 50 (2), 484-515.

Cardenas, Juan-Camilo, John Stranlund, and Cleve Willis, "Local Environmental Control and Institutional Crowding-Out," World Development, 2000, 28 (10), 1719-1733.

Carvalhoa, Leandro S., Silvia Prinab, and Justin Sydnor, "The Effect of Saving on Risk Attitudes and Intertemporal choices," Journal of Development Economics, 2016, 120 (C), $41-52$.

Cassar, Alessandra, Andrew Healy, and Christian von Kessler, "Trust, Risk and Time Preferences After Natural Disasters," World Development, 2017, 94.

Charness, Gary, Uri Gneezy, and Alex Imas, "Experimental Methods: Eliciting Risk Preferences," Journal of Economic Behavior and Organization, 2013, 87, 43-51.

Eckel, Catherine C., Mahmoud A. El-Gamal, and Rick K. Wilson, "Risk Loving after the Storm: A Bayesian Network Study of Hurricane Katrina Evacuees," Journal of Economic Behavior and Organization, 2009, 69 (2), 110-124.

Fafchamps, Marcel and Flore Gubert, "The Formation of Risk Sharing Networks," Journal of Development Economics, 2007, 83 (2), 326-350.

and Susan Lund, "Risk-sharing Networks in Rural Philippines," Journal of Development Economics, 2003, 71 (2), 261-287.

Fleming, David A., Alberto Chong, and Hernán D. Bejarano, "Trust and Reciprocity in the Aftermath of Natural Disasters," Journal of Development Studies, 2014, 50 (11), $1482-1493$.

Freeman, Paul and Howard Kunreuther, "Environmental Risk Management for Developing Countries," The Geneva Papers on Risk and Insurance. Issues and Practice, 2002, 27 (2), 196-214. 
Gallagher, Justin, "Learning about an Infrequent Event: Evidence from Flood Insurance TakeUp in the United States," American Economic Journal: Applied Economics, July 2014, 6 (3), 206-323.

Ghatak, Maitreesh, "Group Lending, Local Information and Peer Selection," Journal of Development Economics, 1999, 60 (1), 27-50.

Gray, Clarke L. and Valerie Mueller, "Natural Disasters and Population Mobility in Bangladesh," Proceedings of the National Academy of Sciences, 2012, 109 (16), 6000-6005.

Hanaoka, Chie, Hitoshi Shigeoka, and Yasutora Watanabe, "Do Risk Preferences Change? Evidence from Panel Data before and after the Great East Japan Earthquake," American Economic Journal: Applied Economics, 2018, forthcoming.

Haushofer, Johannes and Ernst Fehr, "On the Psychology of Poverty," Science, 2014, 344 (6186), 862-867.

Holzmann, Robert, Truman Packard, and Jose. Cuesta, "Extending Coverage in Multipillar Pension Systems : Constraints and Hypotheses, Preliminary Evidence and Future Research Agenda," Social Protection Discussion Paper series, 2000, pp. no. SP 0002. Washington, D.C. : The World Bank.

Kousky, Carolyn, "Learning from Extreme Events: Risk Perceptions after the Flood," Land Economics, 2010, 86 (3), 395-422.

, Erwann Michel-Kerjan, and Paul A. Raschky, "Does Federal Disaster Assistance Crowd out Flood Insurance?," Journal of Environmental Economics and Management, 2018, $87,150-164$.

Kriesel, Warren and Craig Landry, "Participation in the National Flood Insurance Program: An Empirical Analysis for Coastal Properties," Journal of Risk and Insurance, 2004, 71 (3), 405-420.

Kunreuther, Howard, "Mitigating Disaster Losses Through Insurance," Journal of Risk and Uncertainty, 1996, 12 (2-3), 171-187.

_ and Mark Pauly, "Neglecting Disaster: Why Don't People Insure against Large Losses?," Journal of Risk and Uncertainty, 2002, 28 (1), 5-21.

__ Nathan Novemsky, and Daniel Kahneman, "Making Low Probabilities Useful," Journal of Risk and Uncertainty, 2001, 23 (2), 103-120.

, Robert Meyer, and Erwann Michel-Kerjan, "Overcoming Decision Biases to Reduce Losses from Natural Catastrophes," 2009. mimeo.

Landry, Craig E., Mona Ahmadiani, and Gregory Colson., "Structural Empirical Analysis of Decisions under Natural Hazard Risk," Working Paper University of Georgia: Athens, 2016, p. GA.

Li, Jin-Zhen, Shu Li, Wen-Zhong Wang, Li-Lin Rao, and Huan Liu, "Are People always more Risk Averse after a Major Snow-hit and a major Earthquake in China in 2008," Applied Cognitive Psychology, 2011, 25, 104-111.

Ligon, Ethan, Jonathan Thomas, and Timothy Worrall, "Informal Insurance Arrangements with Limited Commitment: Theory and Evidence from Village Economies," Review of Economic Studies, 2002, 69 (1), 209-244. 
Lowenstein, George and Erik Angner, "Predicting and Indulging Changing Preferences," in D. Read G. Lowenstein and R. Baumeister(eds), eds., Time and Decision: Economic and Psychological Perspectives on Intertemporal Choice, New York: Russell Sage Foundation, 2003.

Malmendier, Ulrike and Stefan Nagel, "Depression Babies: Do Macroeconomic Experiences Affect Risk Taking?," Quarterly Journal of Economics, 2011, 126 (1), 373-416.

Mazzocco, Maurizio and Shiv Saini, "Testing Efficient Risk Sharing with Heterogeneous Risk Preferences," American Economic Review, February 2012, 102 (1), 428-68.

Morduch, Jonathan, "Consumption Smoothing across Space: Tests for Village-level Responses to Risk," Harvard University mimeo, 1991.

Munshi, Kaivan and Mark Rosenzweig, "Networks and Misallocation: Insurance, Migration, and the Rural-Urban Wage Gap," American Economic Review, 2016, 106 (1), 46-98.

Nations, United, "Aila Cyclone Aila: Joint UN Multisector Assessment \& Response Framework," 2010. Dhaka, June.

Page, Lionel, David Savage, and Benno Torgler, "Variation in Risk Seeking Behaviour Following Large Losses: A Natural Experiment," European Economic Review, 2014, 71 (C), $121-131$.

Petrolia, Daniel R., Craig E. Landry, and Keith H. Coble, "Risk Preferences, Risk Perceptions, and Flood Insurance," Land Economics, 2013, 89 (2), 227-245.

Raschky, Paul A. and Hannelore Weck-Hannemann, "Charity Hazard - A Real Hazard to Natural Disaster Insurance?," Environmental Hazards, 2007, 7 (4), 321-329.

, Reimund Schwarze, Manijeh Schwindt, and Ferdinand Zahn, "Uncertainty of Governmental Relief and the Crowding out of Flood Insurance," Environmental and Resource Economics, 2013, 54 (2), 179-200.

Ravallion, Martin and Lorraine Dearden, "Social Security in a "Moral Economy": An Empirical Analysis for Java," Review of Economics and Statistics, 1988, 70, 36-44.

Solnit, Rebecca, A Paradise Built in Hell: The Extraordinary Communities that Arise in Disaster, Viking Books, 2009.

Sutter, Matthias, "Are Teams Prone to Myopic Loss Aversion? An Experimental Study on Individual versus Team Behaviour," Economics Letters, 2007, 97, 128-132.

, Stefan Haigner, and Martin G. Kocher, "Choosing the Carrot or the Stick? Endogenous Institutional Choice in Social Dilemma Situations," Review of Economic Studies, 2010, 77 (4), 1540-1566.

Townsend, Robert M., "Risk and Insurance in Village India," Econometrica, May 1994, 62, $539-591$.

Toya, Hideki and Mark Skidmore, "Do Natural Disasters Enhance Societal Trust?," Kyklos, $2014,67,255-279$.

Voors, Maarten J., Eleonora E. M. Nillesen, Philip Verwimp, Erwin H. Bulte, Robert Lensink, and Daan P. Van Soest, "Violent Conflict and Behavior: A Field Experiment in Burundi," American Economic Review, April 2012, 102 (2), 941-64. 
Weerdt, Joachim De and Stefan Dercon, "Risk-sharing Networks and Insurance Against Illness," Journal of Development Economics, 2006, 81 (2), 337-356.

Yamamura, Eiji, "Natural Disasters and Social Capital Formation: The Impact of the Great Hanshin-Awaji Earthquake," Papers in Regional Science, 2016, 95, 95: S143-S164.

Zylberberg, Yanos and André Gröger, "Internal Labor Migration as a Shock Coping Strategy: Evidence from a Typhoon," American Economic Journal: Applied Economics, 2016, 8 (2), 123-153. 


\section{Tables}

Table 1: Descriptive Statistics

\begin{tabular}{lccc|ccc|cc}
\hline \multicolumn{1}{c}{ Variable } & Obs. & Mean & Std. Dev. & Obs. & Mean & Std. Dev. & Diff. & Std. Error \\
\hline Head Age & 578 & 40.79 & 7.10 & 654 & 46.52 & 12.94 & $5.73^{* * *}$ & $(0.59)$ \\
Head Sex & 578 & 0.01 & 0.11 & 654 & 0.02 & 0.15 & 0.01 & -0.01 \\
Head Edu. & 578 & 4.51 & 4.02 & 653 & 3.39 & 3.98 & $-1.11^{* * *}$ & $(0.23)$ \\
HH Max. Edu. & 578 & 7.85 & 2.46 & 654 & 7.56 & 3.35 & $-0.30^{*}$ & $(0.17)$ \\
HH Size & 578 & 4.82 & 1.29 & 654 & 5.00 & 1.44 & $0.18^{* *}$ & -0.08 \\
Day Labour & 575 & 0.48 & 0.50 & 653 & 0.42 & 0.49 & $-0.06^{* *}$ & -0.03 \\
Agriculture & 575 & 0.10 & 0.30 & 653 & 0.04 & 0.19 & $-0.06^{* * *}$ & -0.01 \\
Business & 575 & 0.33 & 0.47 & 653 & 0.33 & 0.47 & -0.00 & -0.03 \\
service & 575 & 0.06 & 0.23 & 653 & 0.02 & 0.13 & $-0.04^{* * *}$ & -0.01 \\
Self-employed & 575 & 0.01 & 0.07 & 653 & 0.00 & 0.00 & $-0.01^{*}$ & 0.00 \\
Unemployed & 575 & 0.01 & 0.07 & 653 & 0.05 & 0.21 & $0.04^{* * *}$ & -0.01 \\
Fisherman & 575 & 0.01 & 0.07 & 653 & 0.11 & 0.31 & $0.10^{* * *}$ & -0.01 \\
Housewife & 575 & 0.02 & 0.12 & 653 & 0.01 & 0.12 & -0.00 & -0.01 \\
HH Income & 578 & 7287.02 & 2980.35 & 654 & 5894.62 & 3185.91 & $-1392.40^{* * *}$ & -175.7 \\
\hline
\end{tabular}


Table 2: Choice of Gamble by Treatment and Control group

\begin{tabular}{|c|c|c|c|c|c|}
\hline $\begin{array}{c}\text { Lottery } \\
\text { Gamble/choice }\end{array}$ & Expected payoff & $\begin{array}{l}\text { Standard } \\
\text { deviation }\end{array}$ & $\begin{array}{l}\text { Non-Disaster } \\
\text { Group (I) } \\
\text { N=578 }\end{array}$ & $\begin{array}{l}\text { Disaster Group (II) } \\
\quad \mathrm{N}=656\end{array}$ & Difference (II-I) \\
\hline 1) 100 for sure & 100 & 0 & $\begin{array}{c}0.123 \\
(0.329)\end{array}$ & $\begin{array}{c}0.122 \\
(0.327)\end{array}$ & $\begin{array}{l}-0.001 \\
(0.019)\end{array}$ \\
\hline 2) 200 vs. 80 & 140 & 84.85 & $\begin{array}{c}0.137 \\
(0.344)\end{array}$ & $\begin{array}{c}0.136 \\
(0.343)\end{array}$ & $\begin{array}{l}-0.001 \\
(0.020)\end{array}$ \\
\hline 3) 250 vs. 70 & 160 & 127.28 & $\begin{array}{c}0.185 \\
(0.389)\end{array}$ & $\begin{array}{c}0.123 \\
(0.329)\end{array}$ & $\begin{array}{c}-0.061^{* * *} \\
(0.020)\end{array}$ \\
\hline 4) 300 vs. 60 & 180 & 169.71 & $\begin{array}{c}0.263 \\
(0.441)\end{array}$ & $\begin{array}{c}0.215 \\
(0.411)\end{array}$ & $\begin{array}{c}-0.049^{* *} \\
(0.024)\end{array}$ \\
\hline 5) 350 vs 50 & 200 & 212.13 & $\begin{array}{c}0.237 \\
(0.426)\end{array}$ & $\begin{array}{c}0.305 \\
(0.461)\end{array}$ & $\begin{array}{c}0.067^{* * * *} \\
(0.025)\end{array}$ \\
\hline 6) 400 vs. 0 & 200 & 282.84 & $\begin{array}{c}0.055 \\
(0.229)\end{array}$ & $\begin{array}{c}0.101 \\
(0.299)\end{array}$ & $\begin{array}{c}0.044^{* * *} \\
(0.015)\end{array}$ \\
\hline $\begin{array}{c}\text { Risk loving } \\
(=1 \text { if chooses } \\
\text { gamble } 5 \text { or } 6)\end{array}$ & & & $\begin{array}{c}0.292 \\
(0.455)\end{array}$ & $\begin{array}{c}0.404 \\
(0.491)\end{array}$ & $\begin{array}{c}0.11^{* * * *} \\
(0.027)\end{array}$ \\
\hline
\end{tabular}

Notes: Probit regressions, marginal effects reported. District Dummies included.

Standard errors are clustered at the village level. ${ }^{* *}, * *, *$ indicate significance at the 1,5 and $10 \%$-level. 
Table 3: Probability of Risk-Taking

\begin{tabular}{lcccc}
\hline & $(1)$ & $(2)$ & $(3)$ & $(4)$ \\
\hline \multirow{2}{*}{ Disaster Village } & $0.11^{* * *}$ & $0.086^{* *}$ & $0.076^{*}$ & $0.13^{* *}$ \\
& $(0.038)$ & $(0.038)$ & $(0.044)$ & $(0.053)$ \\
Age of Respondent & & -0.0003 & -0.0003 & -0.0003 \\
& & $(0.001)$ & $(0.001)$ & $(0.001)$ \\
Female & $-0.069^{* *}$ & $-0.069^{* *}$ & $-0.071^{* *}$ \\
& $(0.034)$ & $(0.034)$ & $(0.034)$ \\
Education & $0.012^{* * *}$ & $0.012^{* * *}$ & $0.012^{* * *}$ \\
& $(0.004)$ & $(0.004)$ & $(0.004)$ \\
Household Size & 0.0012 & 0.001 & 0.001 \\
& & $(0.011)$ & $(0.011)$ & $(0.011)$ \\
Log(HH Income) & & $-0.067^{* *}$ & $-0.067^{* *}$ & $-0.060^{*}$ \\
& & $(0.034)$ & $(0.034)$ & $(0.034)$ \\
District Dummy & & -0.022 & -0.022 \\
Disaster village $\times$ & & & $(0.042)$ & $(0.042)$ \\
Inundation higher & & & & $-0.090^{* *}$ \\
than median & & & & $(0.044)$ \\
\hline $\mathrm{N}$ & 1232 & 1221 & 1221 & 1221 \\
\hline
\end{tabular}

Notes: Probit regressions, marginal effects reported. District Dummies included. Standard errors are clustered at the village level. ${ }^{* * *},{ }^{* *},{ }^{*}$ indicate significance at the 1,5 and $10 \%$-level. 
Table 4: Probability of Joining a Risk-sharing Group

\begin{tabular}{|c|c|c|c|c|c|c|c|}
\hline Disaster Village & $\begin{array}{c}(1) \\
-0.065^{* * * *} \\
(0.024)\end{array}$ & $\begin{array}{c}(2) \\
0-0.049^{*} \\
(0.026)\end{array}$ & $\begin{array}{c}(3) \\
-0.056^{* *} \\
(0.027)\end{array}$ & $\begin{array}{c}(4) \\
-0.054^{*} \\
(0.028)\end{array}$ & $\begin{array}{c}(5) \\
-0.059^{* *} \\
(0.026)\end{array}$ & $\begin{array}{c}(6) \\
-0.059^{*} \\
(0.029)\end{array}$ & $\begin{array}{c}(7) \\
-0.059^{*} \\
(0.029)\end{array}$ \\
\hline Age & & $\begin{array}{l}-0.0007 \\
(0.0006)\end{array}$ & $\begin{array}{l}-0.0006 \\
(0.0006)\end{array}$ & $\begin{array}{l}-0.0007 \\
(0.0006)\end{array}$ & $\begin{array}{l}-0.0005 \\
(0.0006)\end{array}$ & $\begin{array}{l}-0.0005 \\
(0.0006)\end{array}$ & $\begin{array}{l}-0.0005 \\
(0.0006)\end{array}$ \\
\hline Female & & $\begin{array}{c}0.022 \\
(0.017)\end{array}$ & $\begin{array}{c}0.023 \\
(0.016)\end{array}$ & $\begin{array}{c}0.022 \\
(0.016)\end{array}$ & $\begin{array}{c}0.023 \\
(0.015)\end{array}$ & $\begin{array}{c}0.021 \\
(0.016)\end{array}$ & $\begin{array}{c}0.021 \\
(0.016)\end{array}$ \\
\hline $\begin{array}{l}\text { Education } \\
\text { (Years of } \\
\text { Schooling) }\end{array}$ & & $\begin{array}{c}0.0025 \\
(0.0025)\end{array}$ & $\begin{array}{c}0.0025 \\
(0.0024)\end{array}$ & $\begin{array}{c}0.0028 \\
(0.0024)\end{array}$ & $\begin{array}{c}0.0026 \\
(0.00230)\end{array}$ & $\begin{array}{c}0.0025 \\
(0.0021)\end{array}$ & $\begin{array}{c}0.0025 \\
(0.0021)\end{array}$ \\
\hline Household Size & & $\begin{array}{c}0.0022 \\
(0.0066)\end{array}$ & $\begin{array}{c}0.0022 \\
(0.0066)\end{array}$ & $\begin{array}{c}0.0023 \\
(0.0065)\end{array}$ & $\begin{array}{c}0.0024 \\
(0.0064)\end{array}$ & $\begin{array}{c}0.0021 \\
(0.0064)\end{array}$ & $\begin{array}{c}0.0020 \\
(0.0064)\end{array}$ \\
\hline $\begin{array}{l}\text { Risk Loving in } \\
\text { Round } 1\end{array}$ & & & & $\begin{array}{l}-0.021 \\
(0.017)\end{array}$ & $\begin{array}{l}-0.023 \\
(0.017)\end{array}$ & $\begin{array}{l}-0.020 \\
(0.016)\end{array}$ & $\begin{array}{l}-0.026 \\
(0.039)\end{array}$ \\
\hline $\begin{array}{c}\text { Winner in Round } 1 \\
\text { Gamble }\end{array}$ & & & & & $\begin{array}{c}-0.078^{* * *} \\
(0.021)\end{array}$ & $\begin{array}{c}-0.079^{* * *} \\
(0.022)\end{array}$ & $\begin{array}{c}-0.083^{* * *} \\
(0.034)\end{array}$ \\
\hline Private Defection & & & & & & $\begin{array}{c}0.019 \\
(0.026)\end{array}$ & $\begin{array}{l}0.018 \\
(0.026)\end{array}$ \\
\hline Public Defection & & & & & & $\begin{array}{c}0.012 \\
(0.0280)\end{array}$ & $\begin{array}{c}0.012 \\
(0.028)\end{array}$ \\
\hline $\begin{array}{l}\text { Risk loving } \times \\
\text { Winner in round } 1\end{array}$ & & & & & & & $\begin{array}{l}0.0074 \\
(0.040)\end{array}$ \\
\hline $\mathrm{N}$ & 966 & 956 & 956 & 956 & 956 & 956 & 956 \\
\hline
\end{tabular}

Notes: Probit regressions, marginal effects reported. District Dummies included. Standard errors are clustered at at the village level. . ***, **, * indicate significance at the 1, 5 and $10 \%$-level. 
Table 5: Group Size Conditional on Group Formation

\begin{tabular}{|c|c|c|c|c|c|c|c|c|}
\hline & $(1)$ & $(2)$ & $(3)$ & $(4)$ & $(5)$ & $(6)$ & $\overline{(7)}$ & $(8)$ \\
\hline $\begin{array}{l}\text { Disaster } \\
\text { Village } \\
\text { Age }\end{array}$ & $\begin{array}{c}-0.65^{* *} \\
(0.24)\end{array}$ & $\begin{array}{c}-0.60^{* *} \\
(0.25)\end{array}$ & $\begin{array}{c}-0.55^{* *} \\
(0.26)\end{array}$ & $\begin{array}{c}-0.54^{* *} \\
(0.26)\end{array}$ & $\begin{array}{c}-0.54^{* *} \\
(0.25)\end{array}$ & $\begin{array}{c}-0.60^{* *} \\
(0.25)\end{array}$ & $\begin{array}{c}-0.53^{* *} \\
(0.26)\end{array}$ & $\begin{array}{c}-0.53^{* *} \\
(0.26)\end{array}$ \\
\hline Female & & $\begin{array}{c}0.14 \\
(0.14)\end{array}$ & $\begin{array}{c}0.14 \\
(0.14)\end{array}$ & $\begin{array}{c}0.14 \\
(0.14)\end{array}$ & $\begin{array}{c}0.14 \\
(0.14)\end{array}$ & $\begin{array}{c}0.14 \\
(0.13)\end{array}$ & $\begin{array}{c}0.11 \\
(0.12)\end{array}$ & $\begin{array}{c}0.11 \\
(0.12)\end{array}$ \\
\hline Education & & $\begin{array}{c}0.014 \\
(0.017)\end{array}$ & $\begin{array}{c}0.013 \\
(0.016)\end{array}$ & $\begin{array}{c}0.014 \\
(0.016)\end{array}$ & $\begin{array}{c}0.014 \\
(0.016)\end{array}$ & $\begin{array}{c}0.014 \\
(0.015)\end{array}$ & $\begin{array}{c}0.013 \\
(0.014)\end{array}$ & $\begin{array}{c}0.014 \\
(0.014)\end{array}$ \\
\hline $\begin{array}{l}\text { Household } \\
\text { size }\end{array}$ & $\begin{array}{l}-0.016 \\
(0.043)\end{array}$ & $\begin{array}{l}-0.018 \\
(0.044)\end{array}$ & $\begin{array}{l}-0.018 \\
(0.044)\end{array}$ & $\begin{array}{l}-0.018 \\
(0.044)\end{array}$ & $\begin{array}{l}-0.020 \\
(0.044)\end{array}$ & $\begin{array}{l}-0.025 \\
(0.042)\end{array}$ & $\begin{array}{l}-0.025 \\
(0.042)\end{array}$ & \\
\hline $\begin{array}{l}\text { Log (household } \\
\text { income) }\end{array}$ & & $\begin{array}{l}0.081 \\
(0.16)\end{array}$ & $\begin{array}{l}0.079 \\
(0.16)\end{array}$ & $\begin{array}{l}0.074 \\
(0.16)\end{array}$ & $\begin{array}{l}0.074 \\
(0.16)\end{array}$ & $\begin{array}{l}0.036 \\
(0.14)\end{array}$ & $\begin{array}{l}0.051 \\
(0.14)\end{array}$ & $\begin{array}{l}0.050 \\
(0.14)\end{array}$ \\
\hline Risk Love & & & & $\begin{array}{c}-0.098 \\
(0.11)\end{array}$ & $\begin{array}{c}-0.098 \\
(0.11)\end{array}$ & $\begin{array}{l}-0.11 \\
(0.12)\end{array}$ & $\begin{array}{l}-0.051 \\
(0.12)\end{array}$ & $\begin{array}{l}0.071 \\
(0.24)\end{array}$ \\
\hline Winner R1 & & & & & & $\begin{array}{c}-0.58^{* * * *} \\
(0.14)\end{array}$ & $\begin{array}{c}-0.60^{* * * *} \\
(0.14)\end{array}$ & $\begin{array}{c}-0.58^{* * *} \\
(0.16)\end{array}$ \\
\hline $\begin{array}{l}\text { Private } \\
\text { Defection }\end{array}$ & & & & & & & $\begin{array}{c}0.37 \\
(0.33)\end{array}$ & $\begin{array}{c}0.38 \\
(0.34)\end{array}$ \\
\hline $\begin{array}{l}\text { Public } \\
\text { Defection }\end{array}$ & & & & & & & $\begin{array}{c}0.40 \\
(0.34)\end{array}$ & $\begin{array}{c}0.41 \\
(0.34)\end{array}$ \\
\hline $\begin{array}{l}\text { Risk love } \times \\
\text { Winner R1 }\end{array}$ & & & & & & & & $\begin{array}{l}-0.19 \\
(0.30)\end{array}$ \\
\hline District Dummy & No & No & No & No & $Y e s$ & $Y e s$ & Yes & $Y e s$ \\
\hline $\mathrm{N}$ & 948 & 939 & 939 & 939 & 939 & 939 & 939 & 939 \\
\hline Adj. $R^{2}$ & 0.041 & 0.038 & 0.037 & 0.037 & 0.037 & 0.067 & 0.076 & 0.076 \\
\hline
\end{tabular}

Notes: OLS. Standard errors are clustered at the village level. $* * *, * *, *$ indicate significance at the 1, 5 and $10 \%$-level. 
Table 6: Differences in Risk-sharing and Risk-taking Behaviour Between Disaster and Dondisaster group.

\begin{tabular}{|c|c|c|c|}
\hline \multirow[t]{4}{*}{ Variable } & \multicolumn{3}{|c|}{ Treatments } \\
\hline & No Defection & Private Defection & Public Defection \\
\hline & \multicolumn{3}{|c|}{ Difference estimates } \\
\hline & $\begin{array}{l}\text { Disaster - No } \\
\text { Disaster }\end{array}$ & $\begin{array}{l}\text { Disaster - No } \\
\text { Disaster }\end{array}$ & $\begin{array}{l}\text { Disaster - No } \\
\text { Disaster }\end{array}$ \\
\hline & $\begin{array}{c}-0.054^{* *} \\
(0.024)\end{array}$ & $\begin{array}{c}-0.072^{* *} \\
(0.027)\end{array}$ & $\begin{array}{c}-0.064^{* *} \\
(0.029)\end{array}$ \\
\hline Group Formation & $\mathrm{N}=424$ & $\mathrm{~N}=262$ & $\mathrm{~N}=282$ \\
\hline & $\begin{array}{c}-1.04^{* * *} \\
(0.14)\end{array}$ & $\begin{array}{r}-0.27^{*} \\
(0.16)\end{array}$ & $\begin{array}{c}0.19 \\
(0.16)\end{array}$ \\
\hline Group Size & $\mathrm{N}=387$ & $\mathrm{~N}=245$ & $\mathrm{~N}=260$ \\
\hline Choose Riskv Bet & $\begin{array}{c}0.076^{* *} \\
(0.038) \\
\mathrm{N}=424\end{array}$ & $\begin{array}{c}0.015 * * * \\
(0.042) \\
\mathrm{N}=262\end{array}$ & $\begin{array}{l}0.088^{*} \\
(0.046) \\
\mathrm{N}=282\end{array}$ \\
\hline Defection & & $\begin{array}{c}-0.23^{* * *} \\
(0.048) \\
\mathrm{N}=249\end{array}$ & $\begin{array}{c}-0.21^{* * *} \\
(0.038) \\
\mathrm{N}=264\end{array}$ \\
\hline & $\begin{array}{c}-0.11^{* * *} \\
(0.041)\end{array}$ & $\begin{aligned}-0.100^{*} \\
(0.054)\end{aligned}$ & $\begin{array}{c}-0.120^{* *} \\
(0.049)\end{array}$ \\
\hline Have Near Neighbour in Group & $\mathrm{N}=387$ & $\mathrm{~N}=245$ & $\mathrm{~N}=260$ \\
\hline & $\begin{array}{c}0.041 \\
(0.046)\end{array}$ & $\begin{array}{l}0.11^{* *} \\
(0.047)\end{array}$ & $\begin{array}{c}0.012 \\
(0.025)\end{array}$ \\
\hline Have Distant Neighbour in Group & $\mathrm{N}=387$ & $\mathrm{~N}=245$ & $\mathrm{~N}=260$ \\
\hline Difference in Average Individual & $\begin{array}{c}14.3 \\
(13.9)\end{array}$ & $\begin{array}{c}7.67 \\
(17.1)\end{array}$ & $\begin{array}{l}0.074 \\
(16.9)\end{array}$ \\
\hline Payoff Before Pooling Income & $\mathrm{N}=424$ & $\mathrm{~N}=262$ & $\mathrm{~N}=282$ \\
\hline $\begin{array}{c}\text { Differences in Average Payoff on } \\
\text { Risk Sharing }\end{array}$ & $\begin{array}{c}8.66 \\
(7.83) \\
\mathrm{N}=393\end{array}$ & $\begin{array}{c}49.6^{* * *} \\
(11.6) \\
\mathrm{N}=198\end{array}$ & $\begin{array}{c}9.74 \\
(9.57) \\
\mathrm{N}=231\end{array}$ \\
\hline
\end{tabular}

Notes: Probit regressions, marginal effects reported. Standard errors

are clustered at the village level. ${ }^{* * *},{ }^{* *},{ }^{*}$ indicate significance at the 1,5 and $10 \%$-level. 
Table 7: Probability of Defection in Risk Sharing Commitment

\begin{tabular}{|c|c|c|c|c|c|}
\hline & $(1)$ & $\overline{(2)}$ & $\overline{(3)}$ & $(4)$ & $\begin{array}{c}(5) \\
\text { Round } 2 \\
\text { Winners only }\end{array}$ \\
\hline Disaster & $\begin{array}{c}-0.21^{* * *} \\
(0.050)\end{array}$ & $\begin{array}{c}-0.22^{* * *} \\
(0.053)\end{array}$ & $\begin{array}{c}-0.21^{* * *} \\
(0.054)\end{array}$ & $\begin{array}{c}-0.21^{* * *} \\
(0.054)\end{array}$ & $\begin{array}{c}-0.28^{* * *} \\
(0.056)\end{array}$ \\
\hline Age & & $\begin{array}{l}-0.001 \\
(0.001)\end{array}$ & $\begin{array}{l}-0.001 \\
(0.001)\end{array}$ & $\begin{array}{l}-0.001 \\
(0.001)\end{array}$ & $\begin{array}{c}-0.003^{* *} \\
(0.001)\end{array}$ \\
\hline Female & & $\begin{array}{l}-0.004 \\
(0.029)\end{array}$ & $\begin{array}{l}-0.005 \\
(0.030)\end{array}$ & $\begin{array}{l}-0.008 \\
(0.029)\end{array}$ & $\begin{array}{l}-0.001 \\
(0.045)\end{array}$ \\
\hline Education & & $\begin{array}{c}0.003 \\
(0.003)\end{array}$ & $\begin{array}{c}0.003 \\
(0.003)\end{array}$ & $\begin{array}{c}0.002 \\
(0.003)\end{array}$ & $\begin{array}{c}0.003 \\
(0.006)\end{array}$ \\
\hline Household Size & & $\begin{array}{c}0.022 \\
(0.014)\end{array}$ & $\begin{array}{c}0.021 \\
(0.015)\end{array}$ & $\begin{array}{c}0.021 \\
(0.015)\end{array}$ & $\begin{array}{c}0.027 \\
(0.023)\end{array}$ \\
\hline Risk Loving & $\begin{array}{c}0.021 \\
(0.027)\end{array}$ & $\begin{array}{c}0.018 \\
(0.024)\end{array}$ & $\begin{array}{c}0.020 \\
(0.026)\end{array}$ & $\begin{array}{c}0.10 \\
(0.071)\end{array}$ & $\begin{array}{c}0.098 \\
(0.091)\end{array}$ \\
\hline $\begin{array}{l}\text { Risk Loving } \\
\times \text { Winner R1 }\end{array}$ & & & & $\begin{array}{l}-0.11 \\
(0.095)\end{array}$ & $\begin{array}{l}0.030 \\
(0.12)\end{array}$ \\
\hline Winner R2 & $\begin{array}{c}0.15^{* * *} \\
(0.03)\end{array}$ & $\begin{array}{c}0.15^{* * *} \\
(0.03)\end{array}$ & $\begin{array}{c}0.15^{* * *} \\
(0.03)\end{array}$ & $\begin{array}{c}0.15^{* * *} \\
(0.03)\end{array}$ & \\
\hline Private Defection & $\begin{array}{c}0.083 \\
(0.053)\end{array}$ & $\begin{array}{c}0.078 \\
(0.053)\end{array}$ & $\begin{array}{c}0.061 \\
(0.064)\end{array}$ & $\begin{array}{c}0.056 \\
(0.061)\end{array}$ & $\begin{array}{c}0.054 \\
(0.065)\end{array}$ \\
\hline District Dummy & $N o$ & No & Yes & Yes & Yes \\
\hline $\mathrm{N}$ & 513 & 509 & 509 & 509 & 283 \\
\hline
\end{tabular}

Notes: Probit regressions, marginal effects reported. Standard errors are clustered at the village level.

$* * *, * *, *$ indicate significance at the 1, 5 and $10 \%$-level. 
Online Appendix

A. Additional Information about the Field Experiment 


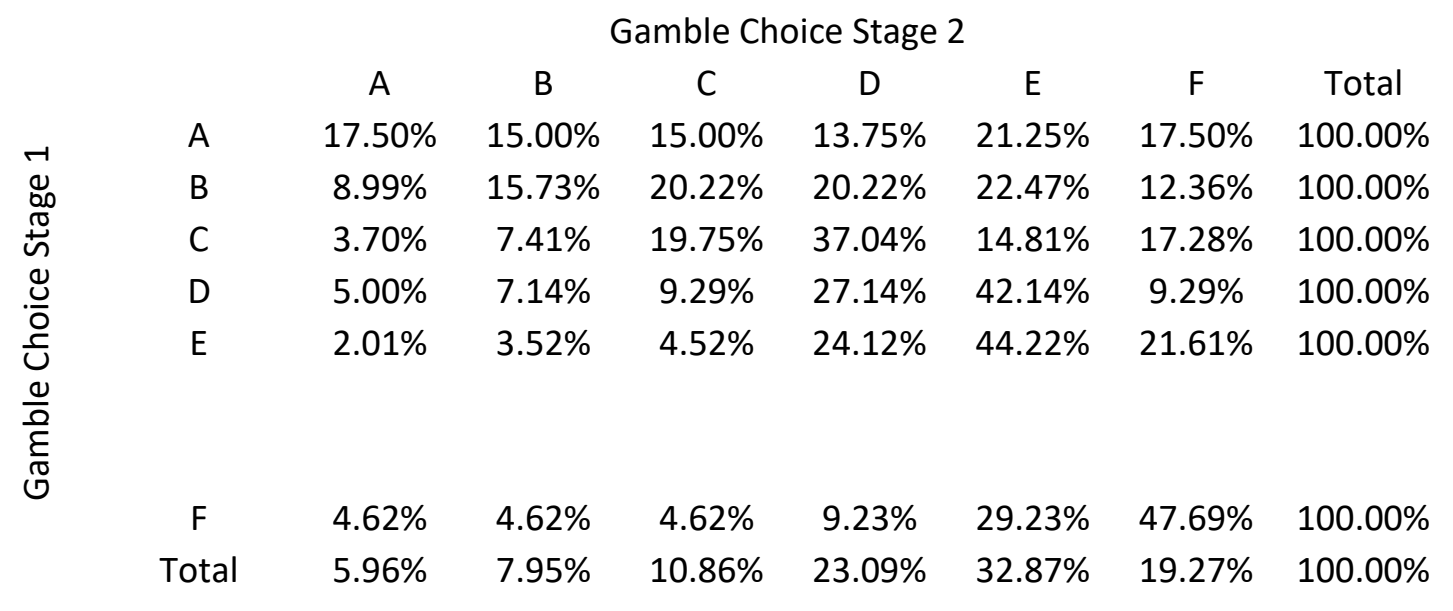

Non Disaster Total

\begin{tabular}{|c|c|c|c|c|c|c|c|c|}
\hline \multirow{7}{*}{ 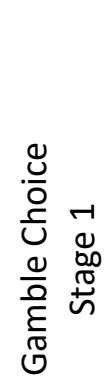 } & \multicolumn{8}{|c|}{ Gamble Choice Stage 2} \\
\hline & & A & B & C & D & $\mathrm{E}$ & $\mathrm{F}$ & Total \\
\hline & A & $7.04 \%$ & $9.86 \%$ & $18.31 \%$ & $25.35 \%$ & $25.35 \%$ & $14.08 \%$ & $100.00 \%$ \\
\hline & B & $2.53 \%$ & $17.72 \%$ & $27.85 \%$ & $21.52 \%$ & $18.99 \%$ & $11.39 \%$ & $100.00 \%$ \\
\hline & C & $0.93 \%$ & $4.67 \%$ & $29.91 \%$ & $33.64 \%$ & $23.36 \%$ & $7.48 \%$ & $100.00 \%$ \\
\hline & D & $2.63 \%$ & $6.58 \%$ & $19.08 \%$ & $32.24 \%$ & $31.58 \%$ & $7.89 \%$ & $100.00 \%$ \\
\hline & $E$ & $2.92 \%$ & $5.11 \%$ & $10.22 \%$ & $24.09 \%$ & $43.07 \%$ & $14.60 \%$ & $100.00 \%$ \\
\hline & $\mathrm{F}$ & $0.00 \%$ & $9.38 \%$ & $9.38 \%$ & $15.63 \%$ & $43.75 \%$ & $21.88 \%$ & $100.00 \%$ \\
\hline & Total & $2.77 \%$ & $7.96 \%$ & $19.55 \%$ & $27.34 \%$ & $30.97 \%$ & $11.42 \%$ & $100.00 \%$ \\
\hline
\end{tabular}

No Group Total

\begin{tabular}{|c|c|c|c|c|c|c|c|c|}
\hline \multirow{8}{*}{ 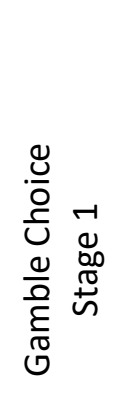 } & \multicolumn{8}{|c|}{ Gamble Choice Stage 2} \\
\hline & & A & B & C & D & $E$ & $\mathrm{~F}$ & Total \\
\hline & A & $7.14 \%$ & $21.43 \%$ & $21.43 \%$ & $35.71 \%$ & $3.57 \%$ & $10.71 \%$ & $100.00 \%$ \\
\hline & B & $2.38 \%$ & $26.19 \%$ & $19.05 \%$ & $16.67 \%$ & $26.19 \%$ & $9.52 \%$ & $100.00 \%$ \\
\hline & C & $0.00 \%$ & $11.36 \%$ & $20.45 \%$ & $40.91 \%$ & $20.45 \%$ & $6.82 \%$ & $100.00 \%$ \\
\hline & D & $7.58 \%$ & $7.58 \%$ & $18.18 \%$ & $16.67 \%$ & $42.42 \%$ & $7.58 \%$ & $100.00 \%$ \\
\hline & $\mathrm{E}$ & $3.33 \%$ & $3.33 \%$ & $8.33 \%$ & $30.00 \%$ & $38.33 \%$ & $16.67 \%$ & $100.00 \%$ \\
\hline & $\mathrm{F}$ & $3.85 \%$ & $3.85 \%$ & $3.85 \%$ & $19.23 \%$ & $57.69 \%$ & $11.54 \%$ & $100.00 \%$ \\
\hline & Total & $4.14 \%$ & $11.28 \%$ & $15.41 \%$ & $25.94 \%$ & $32.71 \%$ & $10.53 \%$ & $100.00 \%$ \\
\hline
\end{tabular}

Forced Group

Total

Gamble Choice Stage 2

\begin{tabular}{|c|c|c|c|c|c|c|c|c|}
\hline \multirow{8}{*}{ 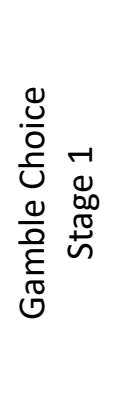 } & & A & B & C & D & $E$ & $F$ & Total \\
\hline & A & $11.11 \%$ & $9.26 \%$ & $12.96 \%$ & $18.52 \%$ & $31.48 \%$ & $16.67 \%$ & $100.00 \%$ \\
\hline & B & $10.91 \%$ & $5.45 \%$ & $23.64 \%$ & $20.00 \%$ & $25.45 \%$ & $14.55 \%$ & $100.00 \%$ \\
\hline & $C$ & $5.36 \%$ & $1.79 \%$ & $30.36 \%$ & $23.21 \%$ & $23.21 \%$ & $16.07 \%$ & $100.00 \%$ \\
\hline & D & $2.60 \%$ & $3.90 \%$ & $16.88 \%$ & $31.17 \%$ & $35.06 \%$ & $10.39 \%$ & $100.00 \%$ \\
\hline & $E$ & $3.31 \%$ & $4.64 \%$ & $6.62 \%$ & $21.19 \%$ & $43.71 \%$ & $20.53 \%$ & $100.00 \%$ \\
\hline & $\mathrm{F}$ & $6.90 \%$ & $3.45 \%$ & $13.79 \%$ & $17.24 \%$ & $17.24 \%$ & $41.38 \%$ & $100.00 \%$ \\
\hline & Total & $5.69 \%$ & $4.74 \%$ & $15.17 \%$ & $22.51 \%$ & $33.65 \%$ & $18.25 \%$ & $100.00 \%$ \\
\hline
\end{tabular}




\begin{tabular}{|c|c|c|c|c|c|c|c|c|}
\hline \multirow{8}{*}{ 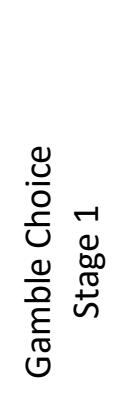 } & \multicolumn{8}{|c|}{ Gamble Choice Stage 2} \\
\hline & & A & B & C & D & E & $\mathrm{F}$ & Total \\
\hline & A & $17.65 \%$ & $11.76 \%$ & $11.76 \%$ & $5.88 \%$ & $35.29 \%$ & $17.65 \%$ & $100.00 \%$ \\
\hline & B & $20.83 \%$ & $0.00 \%$ & $20.83 \%$ & $20.83 \%$ & $25.00 \%$ & $12.50 \%$ & $100.00 \%$ \\
\hline & C & $17.65 \%$ & $5.88 \%$ & $17.65 \%$ & $29.41 \%$ & $5.88 \%$ & $23.53 \%$ & $100.00 \%$ \\
\hline & D & $3.57 \%$ & $3.57 \%$ & $10.71 \%$ & $46.43 \%$ & $28.57 \%$ & $7.14 \%$ & $100.00 \%$ \\
\hline & $E$ & $3.53 \%$ & $3.53 \%$ & $3.53 \%$ & $21.18 \%$ & $43.53 \%$ & $24.71 \%$ & $100.00 \%$ \\
\hline & $\mathrm{F}$ & $10.00 \%$ & $0.00 \%$ & $10.00 \%$ & $10.00 \%$ & $20.00 \%$ & $50.00 \%$ & $100.00 \%$ \\
\hline & Total & $8.90 \%$ & $3.66 \%$ & $9.42 \%$ & $23.04 \%$ & $32.46 \%$ & $22.51 \%$ & $100.00 \%$ \\
\hline
\end{tabular}

Forced Group Non Disaster

\begin{tabular}{|c|c|c|c|c|c|c|c|c|}
\hline \multirow{8}{*}{ 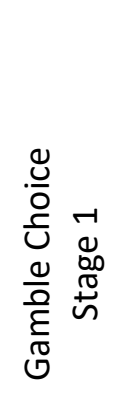 } & \multicolumn{8}{|c|}{ Gamble Choice Stage 2} \\
\hline & & A & B & C & D & $E$ & $F$ & Total \\
\hline & A & $8.11 \%$ & $8.11 \%$ & $13.51 \%$ & $24.32 \%$ & $29.73 \%$ & $16.22 \%$ & $100.00 \%$ \\
\hline & B & $3.23 \%$ & $9.68 \%$ & $25.81 \%$ & $19.35 \%$ & $25.81 \%$ & $16.13 \%$ & $100.00 \%$ \\
\hline & C & $0.00 \%$ & $0.00 \%$ & $35.90 \%$ & $20.51 \%$ & $30.77 \%$ & $12.82 \%$ & $100.00 \%$ \\
\hline & D & $2.04 \%$ & $4.08 \%$ & $20.41 \%$ & $22.45 \%$ & $38.78 \%$ & $12.24 \%$ & $100.00 \%$ \\
\hline & $\mathrm{E}$ & $3.03 \%$ & $6.06 \%$ & $10.61 \%$ & $21.21 \%$ & $43.94 \%$ & $15.15 \%$ & $100.00 \%$ \\
\hline & $\mathrm{F}$ & $0.00 \%$ & $11.11 \%$ & $22.22 \%$ & $33.33 \%$ & $11.11 \%$ & $22.22 \%$ & $100.00 \%$ \\
\hline & Total & $3.03 \%$ & $5.63 \%$ & $19.91 \%$ & $22.08 \%$ & $34.63 \%$ & $14.72 \%$ & $100.00 \%$ \\
\hline
\end{tabular}

Public Defection Total

\begin{tabular}{|c|c|c|c|c|c|c|c|c|}
\hline \multirow{8}{*}{ 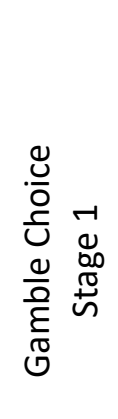 } & \multicolumn{8}{|c|}{ Gamble Choice Stage 2} \\
\hline & & A & B & C & D & $E$ & $\mathrm{~F}$ & Total \\
\hline & A & $21.05 \%$ & $13.16 \%$ & $13.16 \%$ & $10.53 \%$ & $23.68 \%$ & $18.42 \%$ & $100.00 \%$ \\
\hline & B & $3.03 \%$ & $15.15 \%$ & $30.30 \%$ & $24.24 \%$ & $15.15 \%$ & $12.12 \%$ & $100.00 \%$ \\
\hline & C & $2.08 \%$ & $6.25 \%$ & $22.92 \%$ & $39.58 \%$ & $16.67 \%$ & $12.50 \%$ & $100.00 \%$ \\
\hline & D & $5.33 \%$ & $9.33 \%$ & $6.67 \%$ & $36.00 \%$ & $33.33 \%$ & $9.33 \%$ & $100.00 \%$ \\
\hline & $E$ & $0.00 \%$ & $6.67 \%$ & $8.33 \%$ & $18.33 \%$ & $46.67 \%$ & $20.00 \%$ & $100.00 \%$ \\
\hline & $\mathrm{F}$ & $0.00 \%$ & $10.71 \%$ & $3.57 \%$ & $3.57 \%$ & $28.57 \%$ & $53.57 \%$ & $100.00 \%$ \\
\hline & Total & $4.96 \%$ & $9.57 \%$ & $13.12 \%$ & $24.82 \%$ & $29.43 \%$ & $18.09 \%$ & $100.00 \%$ \\
\hline
\end{tabular}

Public Defection Disaster

Gamble Choice Stage 2

\begin{tabular}{|c|c|c|c|c|c|c|c|c|}
\hline \multirow{7}{*}{ 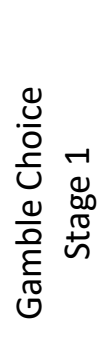 } & & A & B & C & D & $E$ & $\mathrm{~F}$ & Total \\
\hline & A & $28.00 \%$ & $12.00 \%$ & $12.00 \%$ & $8.00 \%$ & $24.00 \%$ & $16.00 \%$ & $100.00 \%$ \\
\hline & B & $6.67 \%$ & $20.00 \%$ & $13.33 \%$ & $26.67 \%$ & $20.00 \%$ & $13.33 \%$ & $100.00 \%$ \\
\hline & C & $0.00 \%$ & $4.17 \%$ & $25.00 \%$ & $41.67 \%$ & $8.33 \%$ & $20.83 \%$ & $100.00 \%$ \\
\hline & D & $9.76 \%$ & $9.76 \%$ & $2.44 \%$ & $21.95 \%$ & $46.34 \%$ & $9.76 \%$ & $100.00 \%$ \\
\hline & $E$ & $0.00 \%$ & $5.26 \%$ & $10.53 \%$ & $10.53 \%$ & $50.00 \%$ & $23.68 \%$ & $100.00 \%$ \\
\hline & $\mathrm{F}$ & $0.00 \%$ & $8.70 \%$ & $4.35 \%$ & $4.35 \%$ & $30.43 \%$ & $52.17 \%$ & $100.00 \%$ \\
\hline & Total & $7.23 \%$ & $9.04 \%$ & $10.24 \%$ & $18.07 \%$ & $33.73 \%$ & $21.69 \%$ & $100.00 \%$ \\
\hline
\end{tabular}

Public Defection Non Disaster

Gamble Choice Stage 2

\begin{tabular}{|c|c|c|c|c|c|c|c|c|}
\hline \multirow{5}{*}{ 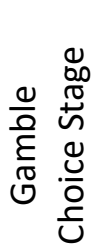 } & & $A$ & B & C & D & $E$ & $\mathrm{~F}$ & Total \\
\hline & $A$ & $7.69 \%$ & $15.38 \%$ & $15.38 \%$ & $15.38 \%$ & $23.08 \%$ & $23.08 \%$ & $100.00 \%$ \\
\hline & B & $0.00 \%$ & $11.11 \%$ & $44.44 \%$ & $22.22 \%$ & $11.11 \%$ & $11.11 \%$ & $100.00 \%$ \\
\hline & $C$ & $4.17 \%$ & $8.33 \%$ & $20.83 \%$ & $37.50 \%$ & $25.00 \%$ & $4.17 \%$ & $100.00 \%$ \\
\hline & D & $0.00 \%$ & $8.82 \%$ & $11.76 \%$ & $52.94 \%$ & $17.65 \%$ & $8.82 \%$ & $100.00 \%$ \\
\hline
\end{tabular}




$\begin{array}{clllllll}\text { E } & 0.00 \% & 9.09 \% & 4.55 \% & 31.82 \% & 40.91 \% & 13.64 \% & 100.00 \% \\ \text { F } & 0.00 \% & 20.00 \% & 0.00 \% & 0.00 \% & 20.00 \% & 60.00 \% & 100.00 \% \\ \text { Total } & 1.72 \% & 10.34 \% & 17.24 \% & 34.48 \% & 23.28 \% & 12.93 \% & 100.00 \%\end{array}$

Private Defection Total

\begin{tabular}{|c|c|c|c|c|c|c|c|c|}
\hline \multirow{7}{*}{ 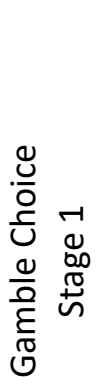 } & \multicolumn{8}{|c|}{ Gamble Choice Stage 2} \\
\hline & & $A$ & B & C & D & $\mathrm{E}$ & $\mathrm{F}$ & Total \\
\hline & A & $9.68 \%$ & $9.68 \%$ & $22.58 \%$ & $16.13 \%$ & $25.81 \%$ & $16.13 \%$ & $100.00 \%$ \\
\hline & B & $5.26 \%$ & $23.68 \%$ & $23.68 \%$ & $23.68 \%$ & $13.16 \%$ & $10.53 \%$ & $100.00 \%$ \\
\hline & C & $0.00 \%$ & $5.00 \%$ & $27.50 \%$ & $40.00 \%$ & $17.50 \%$ & $10.00 \%$ & $100.00 \%$ \\
\hline & D & $0.00 \%$ & $6.76 \%$ & $16.22 \%$ & $33.78 \%$ & $36.49 \%$ & $6.76 \%$ & $100.00 \%$ \\
\hline & $E$ & $1.54 \%$ & $1.54 \%$ & $4.62 \%$ & $30.77 \%$ & $46.15 \%$ & $15.38 \%$ & $100.00 \%$ \\
\hline & $\mathrm{F}$ & $0.00 \%$ & $7.14 \%$ & $0.00 \%$ & $0.00 \%$ & $35.71 \%$ & $57.14 \%$ & $100.00 \%$ \\
\hline & Total & $2.29 \%$ & $8.02 \%$ & $16.03 \%$ & $28.63 \%$ & $31.30 \%$ & $13.74 \%$ & $100.00 \%$ \\
\hline
\end{tabular}

Private Defection Disaster

\begin{tabular}{|c|c|c|c|c|c|c|c|c|}
\hline \multirow{8}{*}{ 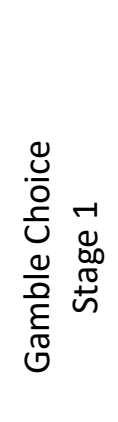 } & \multicolumn{8}{|c|}{ Gamble Choice Stage 2} \\
\hline & & A & B & C & D & $\mathrm{E}$ & $\mathrm{F}$ & Total \\
\hline & A & $15.79 \%$ & $10.53 \%$ & $21.05 \%$ & $5.26 \%$ & $26.32 \%$ & $21.05 \%$ & $100.00 \%$ \\
\hline & B & $10.53 \%$ & $10.53 \%$ & $21.05 \%$ & $21.05 \%$ & $21.05 \%$ & $15.79 \%$ & $100.00 \%$ \\
\hline & C & $0.00 \%$ & $0.00 \%$ & $26.32 \%$ & $31.58 \%$ & $21.05 \%$ & $21.05 \%$ & $100.00 \%$ \\
\hline & D & $0.00 \%$ & $5.41 \%$ & $8.11 \%$ & $32.43 \%$ & $40.54 \%$ & $13.51 \%$ & $100.00 \%$ \\
\hline & $\mathrm{E}$ & $2.22 \%$ & $2.22 \%$ & $2.22 \%$ & $31.11 \%$ & $44.44 \%$ & $17.78 \%$ & $100.00 \%$ \\
\hline & $\mathrm{F}$ & $0.00 \%$ & $11.11 \%$ & $0.00 \%$ & $0.00 \%$ & $22.22 \%$ & $66.67 \%$ & $100.00 \%$ \\
\hline & Total & $4.05 \%$ & $5.41 \%$ & $11.49 \%$ & $25.00 \%$ & $33.78 \%$ & $20.27 \%$ & $100.00 \%$ \\
\hline
\end{tabular}

Private Defection Non Disaster

Gamble Choice Stage 2

\begin{tabular}{|c|c|c|c|c|c|c|c|c|}
\hline \multirow{8}{*}{ 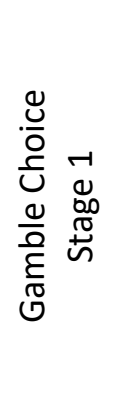 } & & A & B & C & D & $E$ & $\mathrm{~F}$ & Total \\
\hline & A & $0.00 \%$ & $8.33 \%$ & $25.00 \%$ & $33.33 \%$ & $25.00 \%$ & $8.33 \%$ & $100.00 \%$ \\
\hline & B & $0.00 \%$ & $36.84 \%$ & $26.32 \%$ & $26.32 \%$ & $5.26 \%$ & $5.26 \%$ & $100.00 \%$ \\
\hline & $C$ & $0.00 \%$ & $9.52 \%$ & $28.57 \%$ & $47.62 \%$ & $14.29 \%$ & $0.00 \%$ & $100.00 \%$ \\
\hline & D & $0.00 \%$ & $8.11 \%$ & $24.32 \%$ & $35.14 \%$ & $32.43 \%$ & $0.00 \%$ & $100.00 \%$ \\
\hline & $E$ & $0.00 \%$ & $0.00 \%$ & $10.00 \%$ & $30.00 \%$ & $50.00 \%$ & $10.00 \%$ & $100.00 \%$ \\
\hline & $\mathrm{F}$ & $0.00 \%$ & $0.00 \%$ & $0.00 \%$ & $0.00 \%$ & $60.00 \%$ & $40.00 \%$ & $100.00 \%$ \\
\hline & Total & $0.00 \%$ & $11.40 \%$ & $21.93 \%$ & $33.33 \%$ & $28.07 \%$ & $5.26 \%$ & $100.00 \%$ \\
\hline
\end{tabular}


Table A1: Sampling for Risk Taking/risk-sharing Game:

\begin{tabular}{|l|c|c|c|c|c|c|}
\hline \multirow{2}{*}{ Type of Game } & \multicolumn{2}{|c|}{ Disaster Area } & \multicolumn{2}{c|}{ Non-disaster Area } & \multicolumn{2}{c|}{ Total } \\
\cline { 2 - 7 } & Village & Sample & Village & Sample & Village & Sample \\
\hline 2.1 (General Group) & 8 & 196 & 8 & 232 & 16 & 428 \\
\hline 2.2 (Private Group) & 5 & 148 & 4 & 115 & 9 & 263 \\
\hline 2.3 (Public Group) & 5 & 166 & 4 & 116 & 9 & 282 \\
\hline 3 (Control, single) & 6 & 149 & 5 & 117 & 11 & 266 \\
\hline total & 24 & 659 & 21 & 580 & 45 & 1239 \\
\hline
\end{tabular}




\section{Instruction for the local experimental assistants/survey enumerators}

Please note that the purpose of study is to learn about human behaviour. The participants in the survey will receive 150 Taka as a courtesy and compensation for their time. In addition to answering survey questions, participants will take part in economic decision making experiments, whereby they will get opportunity to earn additional money. It is important that participants do not discuss the money earned in the experiment with other villagers as this might create unnecessary problem on the part of researchers for continuing the study.

\section{Design of the study:}

- From each village, we select only those households who were interviewed (randomly0 in our 2010 Aila/early 2011 school survey.

- The survey will take place at early morning.

- The economic experiments will be played on the same day.

- Each enumerator will interview 2 households/day.

- After the survey is complete, the enumerators will inform the interviewee household member that as a part of the study her/his financial decision making behaviour will be investigated through simple experiments using lottery procedure. In such experiments the interviewee will be given the opportunity to earn additional money. This will be conducted in a particular location to be confirmed at the time. In the event the interviewee is unable to come for experiments, an adult (over 18 years) representative from the same household (male/female) will be invited to participate in the economic experiment. The survey participation fee and any money earned during the experiment will all be given cash to participants once everything is completed.

Note: if there are other people whom we did not survey in 2010/2011 but want to participate at the experiment/answer survey, we politely tell them the following "We are very sorry. Our sirs (researchers) randomly selected these households from the census/voter list and we are not allowed to interview anyone BUT the household in the given list".

First Experiment: This experiment will be played individually by all participants in $\mathbf{2 4}$ disaster affected (treatment) villages and 21 non-affected (control villages for school project) villages. The experiment will be played just after lunch. Here each enumerator will conduct the first experiment with the households/individuals whom they surveyed. These villages will be selected (randomly) from our list of 50 Aila (treatment) village and 33 school project (control) villages. Once the villages have been selected, assign the name of villages for the enumerators.

First, each participant plays the Decision-making Experiment I, individually and winnings will be distributed at the end of first round of play.

(Note: we will actually not pay them at this stage. Enumerators will tell the participants that this money will be paid at the end of the day when all experiments are complete and all decisions are recorded)

At the end of the first experiment, participants will be told to take an hour break and play the same experiment for a second time. They will be informed before the break (and after the first experiment) that they can if they wish form groups with other participants and that those in a group will share second round of experiment winnings equally. There will be no restrictions on the size or composition of groups. They can play alone or form group with as many people as they want. But they will have to form the group with people who played the first experiment. No new participants will be allowed for this experiment. All the people in experiment 1 will play the experiment 2 .

Before taking break for the $2^{\text {nd }}$ round and before they play the $2^{\text {nd }}$ experiment, participants will attend a short training session during which they will be shown how group formation secure some earning for everyone and how and to what extent the grouping arrangements will be enforced. 
Before the start of the $2^{\text {nd }}$ experiment after the break, participants will be asked to declare whether they have formed a group or not and if yes with whom. Participants in a group have to register together and their intention to form a group is recorded by the enumerators. After all groups will have to be declared and agreed on, each participant will proceed to make similar decision making task individually and privately.

\section{Risk-sharing experiment:}

Experiment 2, Type 1: (8 disaster affected villages, and 8 non-disaster affected village): At the end of play, winnings are calculated, pooled and shared equally for those in groups, and privately distributed to all participants. Once participants have declared a group, they cannot subsequently change their mind, i.e., they cannot refuse to share their earning from the $2^{\text {nd }}$ round with others in their group. So, regardless of the individual earning amount in the second round, everyone's earning amount will be pooled and then shared equally. These villages will be selected from 24 Aila villages and 21 control villages which have been (randomly) chosen to play experiment 1

\section{Experiment 2, Type 2: (DIFFERENT 5 disaster affected villages, and DIFFERENT 4 non-disaster} affected village): Same procedure as above. That is, they will be asked to form group. They can play alone or play with as many participants as they want. However, under treatment 2, after having made individual choice and subsequent individual earnings (but not those of others in their group), participants are allowed to opt out of their sharing groups in secret by telling to enumerators, i.e., they can decide to keep their individual winnings and leave the group.

Remember they could decide whether to stay or to opt out only after learning the outcome of their own choice (but without knowing other group members" choice or earning of others') and while alone with the enumerator. If they opt to do so, they do not receive a share of the winnings of others in their group. For those in the group who did not quit knowing own earning and stayed in the group, the rest of the gains within the group will be pooled and divided equally between the remaining group members. After experiment 1, type 1 is being played, this experiment will be played in 5 Aila villages and 4 non-alia villages selected for experiment 1 , but were not played in experiment 2 , type 1 .

Experiment 3, Type 3: (DIFFERENT 5 disaster affected villages, and DIFFERENT 4 non-disaster affected village): Treatment 3 is similar to treatment 2 above. This experiment will be played in the remaining 5 Aila villages and 4 non-alia villages. Participants will be told that that they could publicly opt out of their sharing groups (after seeing the outcome of his/her own experiment but not the others). The difference with treatment 2 is that if participants want to keep their individual winnings after playing his/her own $2^{\text {nd }}$ experiment; participants will have to declare the decision of leaving the group publicly in front of everyone participating in the same experimental session.

Control: (DIFFERENT 6 disaster affected villages and DIFFERENT 5 non-disaster affected village): Here we will not play any risk-sharing experiment. Instead, enumerators will tell the interviewees after the first round experiment that we will play the same game once more. The same experiment will be played individually, and exactly the same way as the first round (experiment 1). Each person will get the money based on his/her winnings from the experiment. They will not form the group with others and will not share the money with others.

Small survey: Each participant will answer a small survey at the end of both experiments to understand the relationship among the members who form group. If someone did not form group but participated in the experiment, we still need to ask him to answer the relevant part of the survey.

Pay the participation fee and any additional money people earn in the experiment only after the experiment and the surveys are all over.

Participation fee: Everybody who will participate in survey and experiment (all rounds, morning and afternoon) will be paid 150 Taka as participation fee. 
All earnings and payments, separately for each round, should be recorded against individual ID from the household survey questionnaire so we are able to match these people with their responses in the household survey

\section{Preparation for the next Day:}

At the end of the first day, enumerators will go to the nearby villages chosen beforehand for survey and experiment scheduled in the next day. On that evening/afternoon, enumerators will go to all the households in that village to identify the households surveyed in 2010 and to tell them that they will come next day for survey and the experiment. Households will also be told that they will also be paid for their time in the survey and they will get the opportunity to earn additional money in simple decision making experiment. They will confirm the participation of an adult member of the respective household for survey and experiment in the next day. Inform that we need an adult person who would respond to survey and play the experiment, and the participants will need to be available for the entire day. 


\section{Instruction for risk game}

Here we are interested to learn about human behavior, in particular how people make decisions/choices facing uncertain monetary prospects

We will ask you some questions and give you opportunity to choose from alternative financial outcomes whereby you choose between a guaranteed earning versus a series of lottery. You will actually be paid in cash at the end of our survey, whatever you earn as consequences of your choice.

Now I will ask you to choose between two different monetary outcomes for you involving chances similar to tossing a coin. [Interviewer: show a coin toss to the subject.] For example, if we toss a coin the chance of turning Head is exactly equal to the chance of turning Tail. Can you tell me what the chance of turning out Head is, if you toss a coin? [If the respondent's answer is wrong then clearly explain to her the right answer.]

1. The respondent answered correctly that the chance is $50 \%$.

2. The respondent was explained the right answer and understood well The respondent was explained, but still could not understand.

Now, suppose you are given the following six options. [Interviewer: show PICTURE] Which option would you choose? YOU WILL ACTUALLY BE PAID THE FINAL EARNING FROM YOUR CHOICE. Circle ONE option you like:

1) You get 100 taka for sure!

2) A coin is tossed and if it is head you get 200 taka and if it is tail you get 80 taka

3) A coin is tossed and if it is head you get 250 taka and if it is tail you get 70 taka

4) A coin is tossed and if it is head you get 300 taka and if it is tail you get 60 taka

5) A coin is tossed and if it is head you get 350 taka and if it is tail you get 50 taka

6) A coin is tossed and if it is head you get 400 taka and if it is tail you get zero taka

Before you make your actual choice, for your understanding let us practice each of the options above by tossing coins. [Enumerator ensures that respondents clearly understand what it means by 50-50 chance of turning head and tail when tossing a coin.] 
ফ্লিপ চার্ট
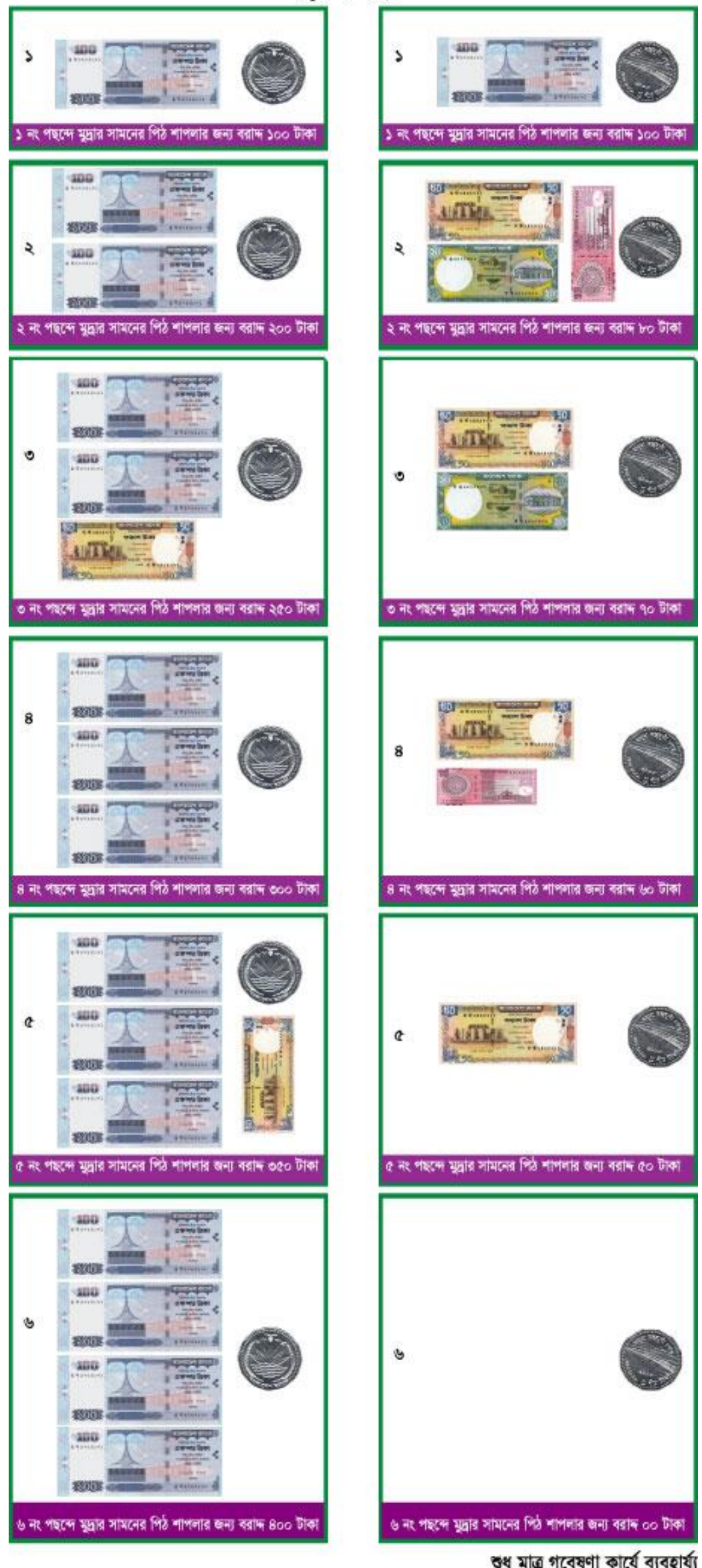

অরू মাত্র গরেষণা হার্যে ব্যবহার্য্য 


\section{INCOME SHARING EXPERIMENT}

Control group statement: In the afternoon we will give you similar second round opportunity to earn money using the same procedure as in the first round.

>> > >> introduce the similar choice context and pictures and remind that we will ask the same questions again in the second round $\gg>>>>>>>$

>>>>>>>>choice context and pictures $>>>>>$

Treatment 1:

In the afternoon we will give you similar second round opportunity to earn money using the same procedure as in the first round.

In this second round, you will be asked first to form your income sharing group, whereby group earnings (sum of group member's private earning) will be shared equally by all members.

The group can consist of single person or as many person as you like. You are free to choose your group MEMBERS (FROM your family, friends, relatives, neighbors, and other villagers. please keep in mind that when you will form your group you are actually agreeing to share the total group income among group members, no matter what each member earn from their own choice as in the first round.

>>>>>>>introduce the similar choice context and pictures and remind that we will ask the same questions again in the second round $>>>>>>>>$

Choice context and pictures

TREATMENT 1 group statement: Like the first round, all group members' private choices AND EARNINGS will be recorded by our enumerators. Then we will calculate total group earnings, which will be later divided equally among group members. So it does not matter what one member earn from his private choice, all will earn equal amount at the end. However, if total earning of group members is zero then none gets any money. Similarly if all but one members private earning is zero then the only earners income will be divided among everybody in the group. this we essentially call income sharing group allowing losers to be compensated by gainers income and this is done by dividing total income equally among all group members. Once participants have declared a group, they cannot subsequently change their mind, i.e., they cannot refuse to share their second day winnings with others in their group. So, regardless of the outcomes of all their gambles, their winnings are pooled and shared equally.

>>>>>>>introduce the similar choice context and pictures and remind that we will ask the same questions again in the second round $\gg \gg>>>>>>$

>>>>>>>>choice context and pictures $\gg>>>>$

For example, if three of you form a group and whatever each of you earn as a result of your own choices will be first put in a fund and then be distributed to you all equally, no matter how much you earned from your individual choice. If person 1 earns 200 Taka, Person 2 earns 400 Taka and Person 3 earns nothing from their individual choices- then we will sum all three earnings and divide them equally to each so that each gets about 200( 600 divided by 3 )!

So remember when you will form group, you are committing to each other to the effect that no matter how much you earn individually from your choice, all of your total learning will be shared equally even if some of you earn more than others or some of you earn nothing out of your individual choices. Please note that group members will have to accept that the total all members earnings will be divided by the number of members so that each gets equal share of total earning from our experiment today. 


\section{TREATMENT 2 STATEMENT}

Treatment 2 group statements: Like the first round, all group members private choices AND EARNINGS will be recorded by our enumerators. Then we will calculate total group earnings, which will be later divided equally among group members. So it does not matter what one member earn from his private choice, all will earn equal amount at the end. However, if total earning of group members is zero then none gets any money. Similarly if all but one members private earning is zero then the only earners income will be divided among everybody in the group. This we essentially call income sharing group allowing losers to be compensated by gainers income and this is done by dividing total income equally among all group members.

>>>>>>>introduce the similar choice context and pictures and remind that we will ask the same questions again in the second round $>>>>>>>>$

>>>>>>>choice context and pictures $\gg>>>>$

For example, if three of you form a group and whatever each of you earn as a result of your own choices will be first put in a fund and then be distributed to you all equally, no matter how much you earned from your individual choice. If person 1 earns 200 Taka, Person 2 earns 400 Taka and Person 3 earns nothing from their individual choices- then we will sum all three earnings and divide them equally to each so that each gets about 200( 600 divided by 3 )!

It is important for you to note that firstly we will record everyone's private choice and income from the choice. Then tell privately everyone in the group about their private income. Once everyone knows the income from his choice, we will allow if one or more person to secretly quit his group in case if he wishes not to share income and thus quit his group. You will not know who in your group quit in this way. In that case the remaining group members' income (if any) will be totaled and be divided equally among them.

So it is important for you to remember when forming a group that someone (or more than one) may QUIT the group taking his individual income earned from his private choice in the experiment and not sharing with other group members. In that case, the remaining group members' earning will be shared equally among them. Although you would not know if anyone has quit as it will be kept confidential, you should be prepared mentally that it might happen in your group that someone would want to quit. 
TREATMENT 3 group statement: Like the first round, all group members private choices AND EARNINGS will be recorded by our enumerators. Then we will calculate total group earnings, which will be later divided equally among group members. so it does not matter what one member earn from his private choice, all will earn equal amount at the end. However, if total earning of group members is zero then none gets any money. Similarly if all but one members private earning is zero then the only earners income will be divided among everybody in the group. This we essentially call income sharing group allowing losers to be compensated by gainers income and this is done by dividing total income equally among all group members.

>>>>>>>introduce the similar choice context and pictures and remind that we will ask the same questions again in the second round $\gg>>>>>>>$

>>>>>>>choice context and pictures $>>>>>$

For example, if three of you form a group and whatever each of you earn as a result of your own choices will be first put in a fund and then be distributed to you all equally, no matter how much you earned from your individual choice. If person 1 earns 200 Taka, Person 2 earns 400 Taka and Person 3 earns nothing from their individual choices- then we will sum all three earnings and divide them equally to each so that each gets about 200( 600 divided by 3 )!

It is important for you to note that firstly we will record everyone's private choice and income from the choice. Then tell privately everyone in the group about their private income. Once everyone knows the income from his choice, we will allow if one or more person to publicly quit his group in case if he wishes not to share income and thus quit his group. As such decision has to be made in front of everyone in the group /present people You will be able know who in your group quit in this way. In that case the remaining group member's income (if any) will be totalled and be divided equally among them.

So it is important for you to remember when forming a group that someone (or more than one) may QUIT the group taking his individual income earned from his private choice in the experiment and not sharing with other group members. In that case, the remaining group members' earning will be shared equally among them. Although you would eventually get to know who quit the group, you should be prepared from the beginning in forming group that it might happen in your group that someone might quit without sharing income from private choice. 


\section{B. Robustness Test - Balanced Sample}

Table B1: Descriptive Statistics - Balanced Sample

\begin{tabular}{lccc|ccc|cc}
\hline & \multicolumn{9}{c}{ Non-Disaster } & \multicolumn{7}{c}{ Disaster } \\
Variable & Obs. & Mean & Std. Dev. & Obs. & Mean & Std. Dev. & Diff. & Std. Error \\
\hline Head Age & 325 & 39.01 & 8.16 & 545 & 39.10 & 11.79 & 0.089 & $(0.68)$ \\
Head Edu. & 325 & 3.93 & 4.01 & 541 & 3.60 & 3.96 & -0.33 & $(0.28)$ \\
Head Sex & 325 & 0.51 & 0.50 & 545 & 0.47 & 0.50 & -0.044 & $(0.035)$ \\
\hline
\end{tabular}


Table B2: Group Size conditional on Group Formation - Balanced Sample

\begin{tabular}{|c|c|c|c|c|c|c|c|c|}
\hline & (1) & $(2)$ & $(3)$ & $(4)$ & $(5)$ & $(6)$ & $(7)$ & $(8)$ \\
\hline Disaster & $-0.77^{* * *}$ & $-0.76^{* * *}$ & $-0.80^{* * *}$ & $-0.80^{* * *}$ & $-0.80^{* * *}$ & $-0.81^{* * *}$ & $-0.76^{* *}$ & $-0.76^{* *}$ \\
\hline Village & $(0.23)$ & $(0.24)$ & $(0.25)$ & $(0.26)$ & $(0.26)$ & $(0.24)$ & $(0.30)$ & $(0.31)$ \\
\hline Age & & 0.0046 & 0.0046 & 0.0044 & 0.0044 & 0.0059 & 0.0036 & 0.0033 \\
\hline & & $(0.0067)$ & $(0.0067)$ & $(0.0067)$ & $(0.0067)$ & $(0.0067)$ & $(0.0064)$ & $(0.0063)$ \\
\hline Female & & 0.15 & 0.16 & 0.16 & 0.16 & 0.14 & 0.13 & 0.13 \\
\hline & & $(0.16)$ & $(0.16)$ & $(0.16)$ & $(0.16)$ & $(0.16)$ & $(0.16)$ & $(0.15)$ \\
\hline Education & & 0.027 & 0.028 & 0.028 & 0.028 & 0.027 & 0.026 & 0.026 \\
\hline & & $(0.020)$ & $(0.020)$ & $(0.020)$ & $(0.020)$ & $(0.019)$ & $(0.017)$ & $(0.017)$ \\
\hline Household & & 0.01 & 0.01 & 0.01 & 0.01 & 0.00 & -0.00 & 0.00 \\
\hline Size & & $(0.05)$ & $(0.05)$ & $(0.05)$ & $(0.05)$ & $(0.05)$ & $(0.05)$ & $(0.05)$ \\
\hline Log (household & & & & & & & & \\
\hline income) & & $\begin{array}{l}-0.01 \\
(0.16)\end{array}$ & $\begin{array}{l}-0.01 \\
(0.15)\end{array}$ & $\begin{array}{l}-0.02 \\
(0.15)\end{array}$ & $\begin{array}{l}-0.02 \\
(0.15)\end{array}$ & $\begin{array}{l}-0.07 \\
(0.14)\end{array}$ & $\begin{array}{l}-0.03 \\
(0.13)\end{array}$ & $\begin{array}{l}-0.03 \\
(0.13)\end{array}$ \\
\hline Risk Love & & & & $\begin{array}{c}-0.086 \\
(0.11)\end{array}$ & $\begin{array}{r}-0.086 \\
(0.11)\end{array}$ & $\begin{array}{l}-0.076 \\
(0.11)\end{array}$ & $\begin{array}{l}0.015 \\
(0.11)\end{array}$ & $\begin{array}{c}0.23 \\
(0.20)\end{array}$ \\
\hline Winner R1 & & & & & & $\begin{array}{c}-0.62^{* * *} \\
(0.15)\end{array}$ & $\begin{array}{c}-0.63^{* * *} \\
(0.15)\end{array}$ & $\begin{array}{c}-0.50^{* *} \\
(0.18)\end{array}$ \\
\hline Private & & & & & & & 0.28 & 0.29 \\
\hline Defection & & & & & & & $(0.26)$ & $(0.26)$ \\
\hline Public & & & & & & & $0.62^{*}$ & $0.63^{*}$ \\
\hline Defection & & & & & & & $(0.32)$ & $(0.32)$ \\
\hline Risk love $x$ & & & & & & & & -0.34 \\
\hline Winner R1 & & & & & & & & $(0.31)$ \\
\hline $\mathrm{N}$ & 677 & 670 & 670 & 670 & 670 & 670 & 670 & 670 \\
\hline Adj. $R^{2}$ & 0.054 & 0.052 & 0.051 & 0.050 & 0.050 & 0.081 & 0.097 & 0.098 \\
\hline
\end{tabular}

Notes: Probit regressions, marginal effects reported. Standard errors are clustered at the village level. $* * *, * *, *$ indicate significance at the 1, 5 and $10 \%$-level. 
Table B3: Probability of Defection in Risk Sharing Commitment - Balanced Sample

\begin{tabular}{|c|c|c|c|c|c|}
\hline & $(1)$ & $\overline{(2)}$ & $\overline{(3)}$ & (4) & $\begin{array}{c}(5) \\
\text { Round } 2 \\
\text { Winners only }\end{array}$ \\
\hline Disaster & $\begin{array}{c}-0.21^{* * *} \\
(0.050)\end{array}$ & $\begin{array}{c}-0.22^{* * *} \\
(0.053)\end{array}$ & $\begin{array}{c}-0.21^{* * *} \\
(0.054)\end{array}$ & $\begin{array}{c}-0.21^{* * *} \\
(0.054)\end{array}$ & $\begin{array}{c}-0.28^{* * *} \\
(0.056)\end{array}$ \\
\hline Age & & $\begin{array}{l}-0.001 \\
(0.001)\end{array}$ & $\begin{array}{l}-0.001 \\
(0.001)\end{array}$ & $\begin{array}{l}-0.001 \\
(0.001)\end{array}$ & $\begin{array}{c}-0.003^{* *} \\
(0.001)\end{array}$ \\
\hline Female & & $\begin{array}{l}-0.004 \\
(0.029)\end{array}$ & $\begin{array}{l}-0.005 \\
(0.030)\end{array}$ & $\begin{array}{l}-0.008 \\
(0.029)\end{array}$ & $\begin{array}{l}-0.001 \\
(0.045)\end{array}$ \\
\hline Education & & $\begin{array}{c}0.003 \\
(0.003)\end{array}$ & $\begin{array}{c}0.003 \\
(0.003)\end{array}$ & $\begin{array}{c}0.002 \\
(0.003)\end{array}$ & $\begin{array}{c}0.003 \\
(0.006)\end{array}$ \\
\hline Household size & & $\begin{array}{c}0.022 \\
(0.014)\end{array}$ & $\begin{array}{c}0.021 \\
(0.015)\end{array}$ & $\begin{array}{c}0.021 \\
(0.015)\end{array}$ & $\begin{array}{c}0.027 \\
(0.023)\end{array}$ \\
\hline Risk love & $\begin{array}{c}0.021 \\
(0.027)\end{array}$ & $\begin{array}{c}0.018 \\
(0.024)\end{array}$ & $\begin{array}{c}0.020 \\
(0.026)\end{array}$ & $\begin{array}{c}0.10 \\
(0.071)\end{array}$ & $\begin{array}{c}0.098 \\
(0.091)\end{array}$ \\
\hline $\begin{aligned} & \text { Risk love } \\
\times & \text { Winner R1 }\end{aligned}$ & & & & $\begin{array}{l}-0.11 \\
(0.095)\end{array}$ & $\begin{array}{l}0.030 \\
(0.12)\end{array}$ \\
\hline Winner R2 & $\begin{array}{c}0.15^{* * *} \\
(0.03)\end{array}$ & $\begin{array}{c}0.15^{* * *} \\
(0.03)\end{array}$ & $\begin{array}{c}0.15^{* * *} \\
(0.03)\end{array}$ & $\begin{array}{c}0.15^{* * *} \\
(0.03)\end{array}$ & \\
\hline Private Defection & $\begin{array}{c}0.083 \\
(0.053)\end{array}$ & $\begin{array}{c}0.078 \\
(0.053)\end{array}$ & $\begin{array}{c}0.061 \\
(0.064)\end{array}$ & $\begin{array}{c}0.056 \\
(0.061)\end{array}$ & $\begin{array}{c}0.054 \\
(0.065)\end{array}$ \\
\hline District Dummy & No & No & Yes & $Y e s$ & Yes \\
\hline $\mathrm{N}$ & 513 & 509 & 509 & 509 & 283 \\
\hline
\end{tabular}

Notes: Probit regressions, marginal effects reported. Standard errors are clustered at the village level. ${ }^{* * *},{ }^{* *}, *$ indicate significance at the 1,5 and $10 \%$-level. 